\title{
Article \\ Groundwater Suitability for Drinking and Irrigation Using Water Quality Indices and Multivariate Modeling in Makkah Al-Mukarramah Province, Saudi Arabia
}

\author{
Maged El Osta ${ }^{1, *(\mathbb{D}}$, Milad Masoud $^{1}\left(\mathbb{D}\right.$, Abdulaziz Alqarawy $^{1,2}$, Salah Elsayed ${ }^{3}\left(\mathbb{D}\right.$ and Mohamed Gad $^{4}(\mathbb{D})$ \\ 1 Water Research Center, King Abdulaziz University, Jeddah 21589, Saudi Arabia; \\ mhmasoud@kau.edu.sa (M.M.); aalqaraawi@kau.edu.sa (A.A.) \\ 2 Faculty of Meteorology, Environment and Arid Land Agriculture, King Abdulaziz University, \\ Jeddah 21589, Saudi Arabia \\ 3 Agricultural Engineering, Evaluation of Natural Resources Department, Environmental Studies and \\ Research Institute, University of Sadat City, Sadat City 32897, Egypt; salah.emam@esri.usc.edu.eg \\ 4 Hydrogeology, Evaluation of Natural Resources Department, Environmental Studies and Research Institute, \\ University of Sadat City, Sadat City 32897, Egypt; mohamed.gad@esri.usc.edu.eg \\ * Correspondence: melosta@kau.edu.sa
}

check for

updates

Citation: El Osta, M.; Masoud, M.; Alqarawy, A.; Elsayed, S.; Gad, M. Groundwater Suitability for Drinking and Irrigation Using Water Quality Indices and Multivariate Modeling in Makkah Al-Mukarramah Province, Saudi Arabia. Water 2022, 14, 483. https://doi.org/10.3390/w14030483

Academic Editors: Xing Fang, Jiangyong $\mathrm{Hu}$ and Suresh Sharma

Received: 27 December 2021

Accepted: 30 January 2022

Published: 6 February 2022

Publisher's Note: MDPI stays neutral with regard to jurisdictional claims in published maps and institutional affiliations.

Copyright: () 2022 by the authors. Licensee MDPI, Basel, Switzerland. This article is an open access article distributed under the terms and conditions of the Creative Commons Attribution (CC BY) license (https:// creativecommons.org/licenses/by/ $4.0 /)$.

\begin{abstract}
Water shortage and quality are major issues in many places, particularly arid and semiarid regions such as Makkah Al-Mukarramah province, Saudi Arabia. The current work was conducted to examine the geochemical mechanisms influencing the chemistry of groundwater and assess groundwater resources through several water quality indices (WQIs), GIS methods, and the partial least squares regression model (PLSR). For that, 59 groundwater wells were tested for different physical and chemical parameters using conventional analytical procedures. The results showed that the average content of ions was as follows: $\mathrm{Na}^{+}>\mathrm{Ca}^{2+}>\mathrm{Mg}^{2+}>\mathrm{K}^{+}$and $\mathrm{Cl}^{-}>\mathrm{SO}_{4}{ }^{2-}>\mathrm{HCO}_{3}{ }^{2-}>\mathrm{NO}_{3}{ }^{-}>\mathrm{CO}_{3}{ }^{-}$. Under the stress of evaporation and saltwater intrusion associated with the reverse ion exchange process, the predominant hydrochemical facies were $\mathrm{Ca}-\mathrm{HCO}_{3}$, $\mathrm{Na}-\mathrm{Cl}$, mixed Ca-Mg-Cl-SO ${ }_{4}$, and $\mathrm{Na}-\mathrm{Ca}-\mathrm{HCO}_{3}$. The drinking water quality index (DWQI) has indicated that only $5 \%$ of the wells were categorized under good to excellent for drinking while the majority (95\%) were poor to unsuitable for drinking, and required appropriate treatment. Furthermore, the irrigation water quality index (IWQI) has indicated that $45.5 \%$ of the wells were classified under high to severe restriction for agriculture, and can be utilized only for high salt tolerant plants. The majority (54.5\%) were deemed moderate to no restriction for irrigation, with no toxicity concern for most plants. Agriculture indicators such as total dissolved solids (TDS), potential salinity (PS), sodium absorption ratio (SAR), and residual sodium carbonate (RSC) had mean values of 2572.30, $33.32,4.84$, and -21.14 , respectively. However, the quality of the groundwater in the study area improves with increased rainfall and thus recharging the Quaternary aquifer. The PLSR models, which are based on physicochemical characteristics, have been shown to be the most efficient as alternative techniques for determining the six WQIs. For instance, the PLSR models of all IWQs had determination coefficients values of $R^{2}$ ranging between 0.848 and 0.999 in the Cal., and between 0.848 and 0.999 in the Val. datasets, and had model accuracy varying from 0.824 to 0.999 in the Cal., and from 0.817 to 0.989 in the Val. datasets. In conclusion, the combination of physicochemical parameters, WQIs, and multivariate modeling with statistical analysis and GIS tools is a successful and adaptable methodology that provides a comprehensive picture of groundwater quality and governing mechanisms.
\end{abstract}

Keywords: multivariate modeling; physicochemical parameters; water quality indices; hydrochemical facies; GIS techniques 


\section{Introduction}

Groundwater is a life-sustaining and crucial resource of the planet [1] (Busico et al., 2020). Water crises and quality are major concerns in many countries, especially arid and semi-arid regions where water shortages are common, and little attention has generally been given to assessing water quality [2,3]. Arid and semi-arid regions suffer from multiple critical issues such as scarcity of water resources and extensive exploitation of groundwater for different uses [4]. These problems will certainly cause a decline in water tables and the degradation of groundwater quality. Therefore, Wadi Fatimah basin was selected for this study. It is a large basin in Makkah province with an area of about $4869 \mathrm{~km}^{2}$ [5], and is considered the main source of water supply for many cities and villages.

Aquifers are especially vulnerable to the effects of uncontrolled extraction and insufficient land use, putting groundwater quality at danger [6-8]. The quality of water at these resources needs proper attention, especially since pure water is essential for drinking, agriculture, and residential use [9]. Groundwater monitoring is critical to meeting growing water needs in respect of availability and quality, and it must be implemented [10]. Recently, a substantial and expanding body of research examined water resources with a focus on evaluating and understanding hydrochemical properties and groundwater quality by utilizing a variety of effective approaches. Water quality indicators (WQIs), geographic information system (GIS) techniques, statistical methodologies, and multivariate modeling are examples of such strategies [11]. The physicochemical properties of water may be utilized to fully comprehend and identify elements influencing groundwater quality as well as to give vital information for water management. Water characteristic, which is established on physicochemical criteria, gives current information on water facies, various geochemical controlling mechanisms, and water classes [12-14]. Water chemistry and geochemical characteristics provide a good basis for examining trends, describing particular sustainability issues, and transferring knowledge on sources of water, geochemical dynamics, quality of water, and water susceptibility for drinking and irrigation [15,16].

The geochemical characteristics of groundwater are essentially governed by recharging, aquifer metrics, contact time, and specific geochemical mechanisms such as dissolution, mineral solubility, and ion exchange processes [17-20]. Therefore, water quality management should be decided by a complete groundwater quality evaluation with respect to physicochemical features and variables influencing water quality [21-24]. Consequently, derivative approaches for defining the key geochemical factors that govern water quality and analyzing the mixing process between fresh and saline water, such as Piper trilinear diagram, Chadah diagram, Gibbs diagram, and hydrochemical facies evolution diagram (HFE), are appropriate and commonly applied $[25,26]$.

Furthermore, multivariate analyses such as cluster analysis (CA) and principal component analysis (PCA) are effective techniques for identifying key physicochemical characteristics and the interrelationships between these parameters in order to comprehend the major variables driving the distribution of physicochemical metrics in water [27-29]. In addition, finding associations between multiple physicochemical variables may be regarded as a unique step forward towards groundwater quality management using statistical correlation analysis, which has been demonstrated to be a highly suitable approach.

The WQIs are derived from a big data collection containing different water quality metrics from various places. Several WQIs were developed to serve as indicators for assessing water availability in both potable supply and agricultural usage [30-33]. The basic goal of WQIs is to convert large numbers of complicated datasets into quantitative water quality data, contributing to a better understanding of water quality [34]. The drinking water quality index (DWQI) may be developed as a reliable tool described as a value that represents the combined impact of many water quality variables [35]. Therefore, DWQI is calculated by analyzing the cumulative impact of man-made and natural activities based on certain factors in the hydro-geometric properties of the groundwater sample.

Based on experience and judgment, irrigation water quality indices (IWQIs) such as TDS, potential PS, SAR, and RSC can meet the criteria for appropriate controls and further 
evaluating water validity for agricultural purposes [36-38]. For example, the IWQI is a significant and distinct model of these indices utilized in water quality evaluation and agricultural production optimization $[39,40]$.

Based on a variety of physicochemical parameters, statistical approaches, WQIs, geographic information system (GIS) techniques, and multivariate modeling are employed [30,41-43]. Utilization of physicochemical parameters, WQIs, and multivariate modelling with statistical analysis and GIS tools is a successful and practical strategy that provides a complete picture of water quality and governing mechanisms.

Determination of DWQI and IWQI requires a long sequence of calculations to convert multiple numbers from the physicochemical elements data into a single value that reveals the validity of water quality level for drinking and irrigation usage. In order to overcome this problem, PLSR approaches were applied in this work. The PLSR method can be used to select the most effective parameters for calculating the DWQI and IWQI. This, in turn, leads to a reduction in the number of elements utilized in the chemical analysis to determine WQIs as well as a reduction in cost. The PLSR approach is a popular way to describe a linear relationship between independent and dependent parameters [44]. PLSR can reduce many collinear components to a few non-correlated latent variables, decreasing duplicate data and minimizing overfitting or underfitting [45,46]. Based on the advantages of these methods, the WQIs can be simultaneously computed from numerous big data using these approaches.

For that, the goals of this research were to (i) identify hydrochemical facies and geochemical processes using physicochemical metrics; (ii) investigate the geochemical controlling factors influencing the chemistry of water using imitative techniques; (iii) evaluate the appropriateness of groundwater for drinking and irrigation with respect to WQIs; and (iv) evaluate the performance of PLSR models based on investigated physicochemical parameters in forecasting the six WQIs, namely DWQI, IWQI, TDS, SAR, PS, and RSC.

\section{Research Materials and Methods}

\subsection{Area of Study and Description}

Makkah Al-Mukarramah province is considered as one of the most important regions in the KSA because of its religious and historical standing, and the large number of residents and tourists who come visiting. The administrative territory of the Makkah region is bordered in the west by the Red Sea, in the east by Riyadh, in the north by Al-Madinah Al-Munawarah, and in the south by the provinces of Al Bahaand Asir, with an area of about $141,216 \mathrm{~km}^{2}$ (Figure 1b). Topographically, Makkah region is characterized by a great diversity in altitude between $0 \mathrm{~m}$ and $2984 \mathrm{~m}$ above sea level (amsl), while the lithological units that dominate this area belong to pre-Cambrian to Quaternary age (Figure 2).

The Precambrian rocks are mainly late-Proterozoic basaltic to rhyolitic volcanic, volcano-clastic, and epi-clastic rocks of the basic island-arc type that have been repeatedly distorted and metamorphosed by intrusion rocks of various ages and mixtures. Below a layer of horizontally basaltic lava and Quaternary sediments, the Tertiary stratigraphic sequence is apparent. It is primarily made up of clastic rocks that are dominated by sandstone, shale, mudstone, oolitic ironstone, and conglomerates. The average annual precipitation in this region varies between $50 \mathrm{~mm} /$ year and $400 \mathrm{~mm} /$ year with some shifts in dry and wet years. The amount of rain falling on this area represents the main source for recharging the groundwater aquifers. Accordingly, this district contains many Wadies (44 catchments) extending to the north and east, which are characterized by surface and groundwater resources [47]. Therefore, scientific research and projects must be directed to this strategic region in order to sustain its water resources and achieve the Kingdom's "Vision 2030". The present study focuses on Wadi Fatimah basin, which spans a broad area of the south and east part of the Jeddah governorate and extends from NE to SW with about $4869-\mathrm{km}^{2}$ area. It is located between the longitudes $39^{\circ} 15^{\prime}$ and $40^{\circ} 30^{\prime} \mathrm{E}$ and latitudes $21^{\circ} 16^{\prime}$ and $22^{\circ} 15^{\prime} \mathrm{N}$ (Figure 1c). The Quaternary aquifer is the primary source of groundwater for different uses in this Wadi. This aquifer is primarily made up of conglomerates, sandstone, 
and mudstone (Wadi fill deposits) that range in thickness from 10 to $60 \mathrm{~m}$ based on the data of drilled wells in the area. The igneous metamorphic rocks that make up the bedrock of this aquifer are highly fractured and weather-cracked, making them the perfect host for groundwater preservation. The depth of groundwater varies from 1.2 to $50.1 \mathrm{~m}$ from the ground surface, with an average value of $16.7 \mathrm{~m}$ according to the field measurements from 64 drilled wells. Based on this data, a water-level distribution map was constructed to show the flow of groundwater along the Wadi. As shown in Figure 3, the groundwater flow was from the east to west direction towards the Red Sea.

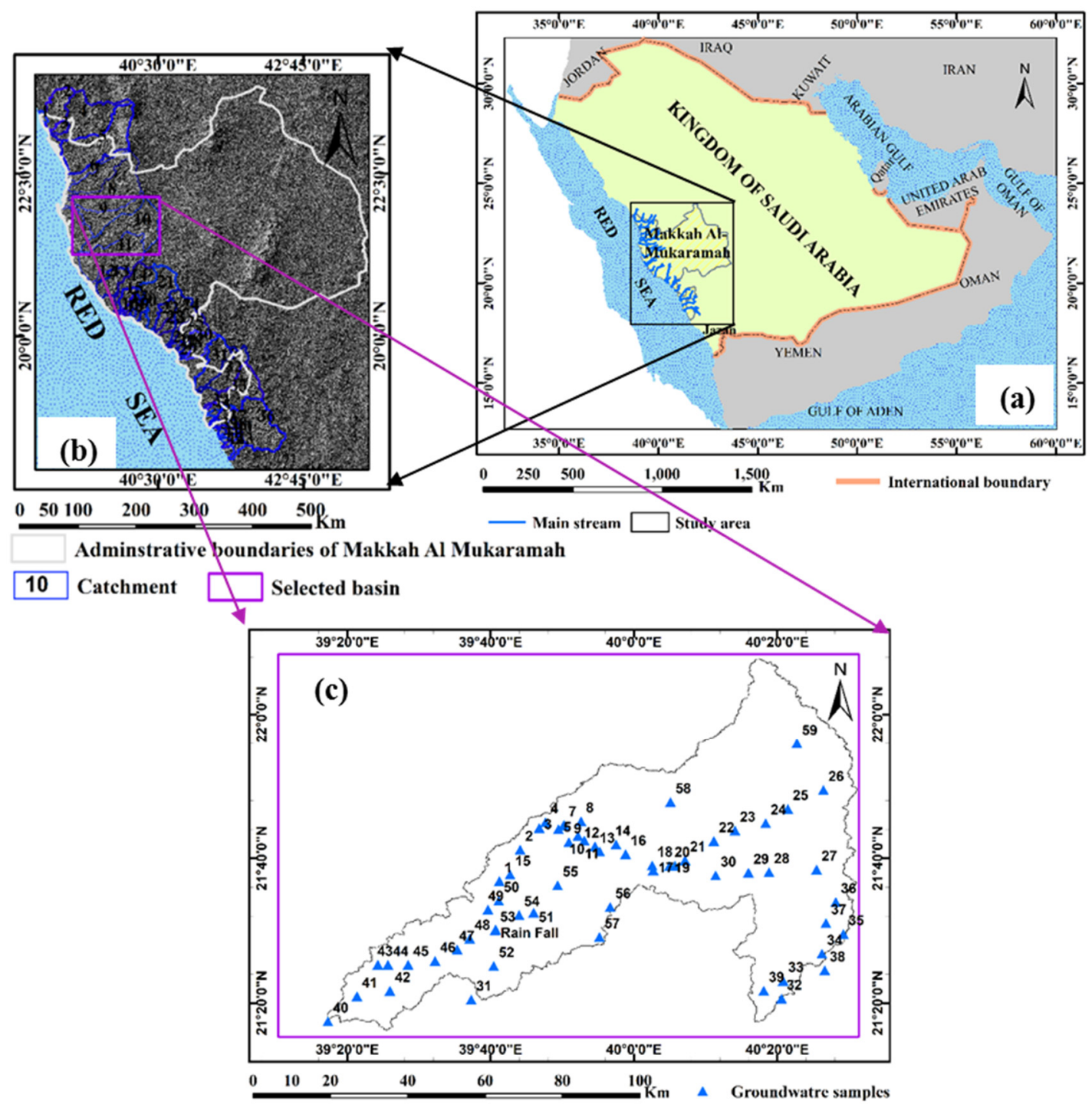

Figure 1. (a) Location map of Makkah Al-Mukarramah province, (b) Wadi Fatimah basin and (c) locations of groundwater samples. 

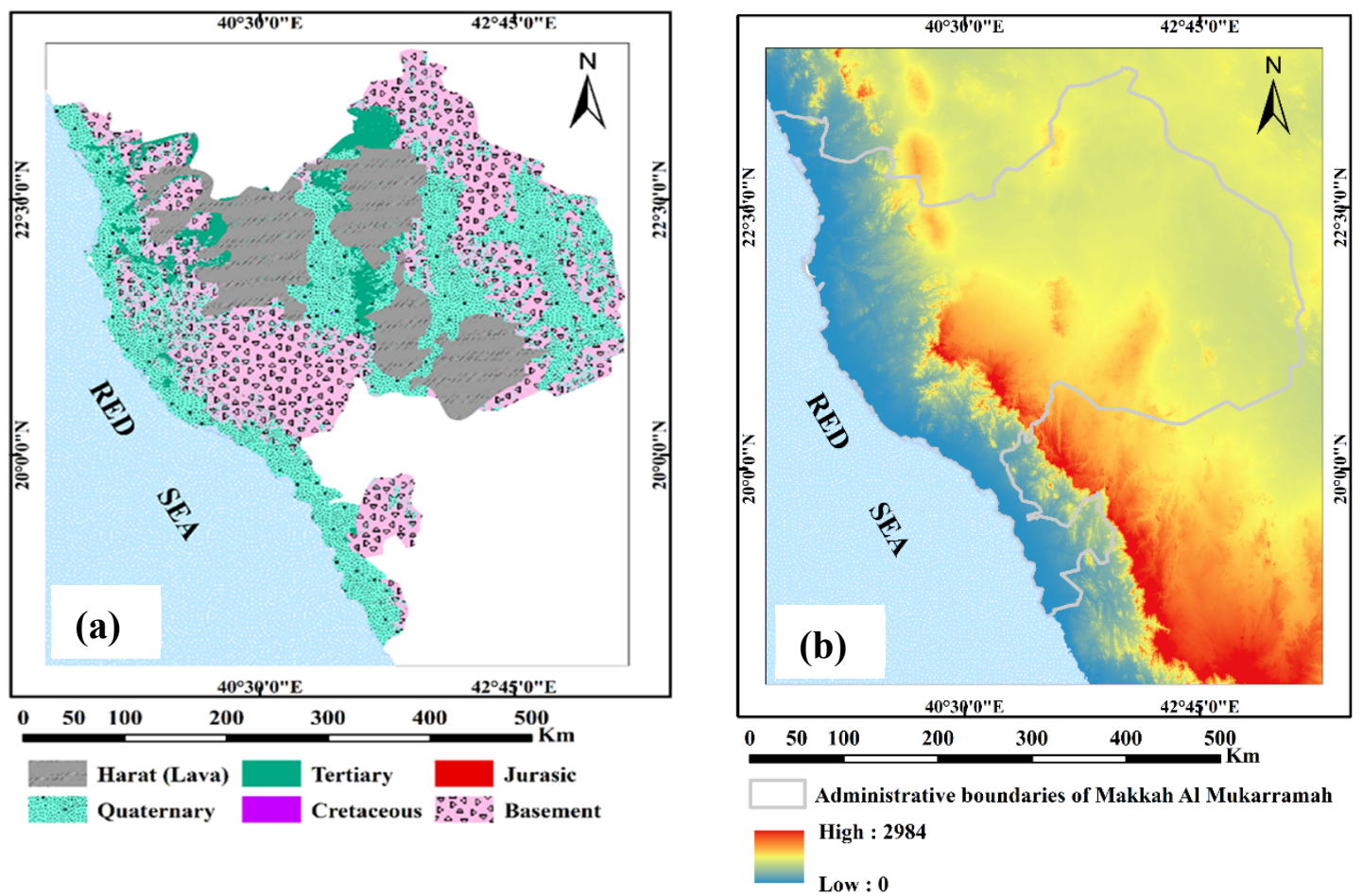

Figure 2. (a) Geological map of Makkah Al-Mukarramah province, and (b) digital elevation model (DEM).

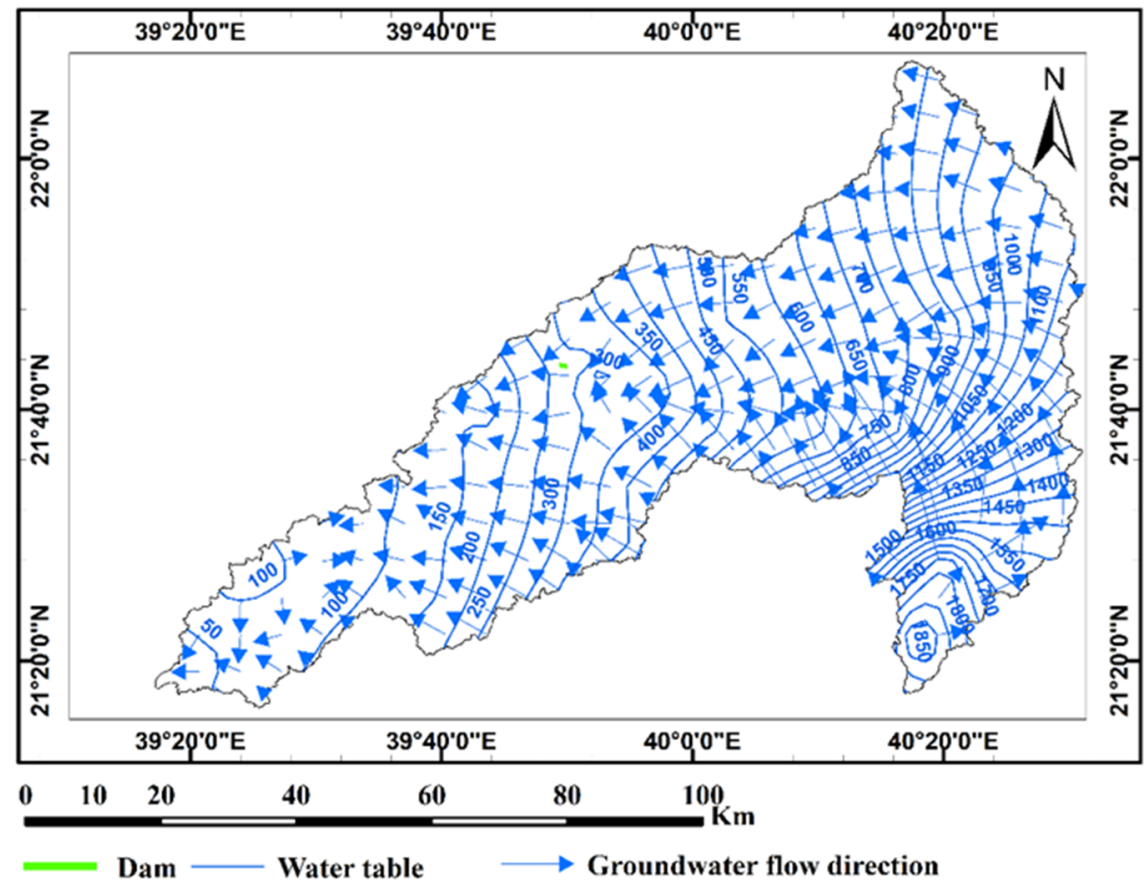

Figure 3. Groundwater elevation contour map in meter (above msl) and flow direction in the area.

\subsection{Samples Collection and Analytical Procedures}

During the year of 2021, 59 samples of groundwater were obtained from the Quaternary aquifer in Wadi Fatimah basin, Makkah Al-Mukarramah province, KSA, for estimating water quality for both drinking and irrigation. Portable Magellan GPS 315 was used to detect the water samples position and identify UTM coordinates of the study area (Figure 1c). The water samples were stored at $4{ }^{\circ} \mathrm{C}$ until they were taken to the laboratory for physicochemical analysis examination. Thirty different physicochemical parameters were detected by standard analytical methods [48]. A portable conductivity multi-parameter apparatus 
was used to measure temperature, $\mathrm{pH}, \mathrm{EC}$, and TDS at the site (Hanna HI 9033), calibrated with standard solutions. $\mathrm{Mg}^{2+}$ and $\mathrm{Ca}^{2+}$ concentrations were determined by the EDTA titrimetric technique using ethylenediaminetetraacetic acid, whereas $\mathrm{K}^{+}$and $\mathrm{Na}^{+}$ concentrations were determined using a flame photometer (ELEX 6361, Eppendorf AG, Hamburg, Germany). The total hardness (TH) was determined using Eriochrome Black-T $\left(\mathrm{C}_{20} \mathrm{H}_{12} \mathrm{~N}_{3} \mathrm{O}_{7} \mathrm{SNa}\right)$ and ammonium chloride $\left(\mathrm{NH}_{4} \mathrm{Cl}\right)$ indicators against EDTA solution. Titration with silver nitrate $\left(\mathrm{AgNO}_{3}\right)$ and potassium chromate $\left(\mathrm{K}_{2} \mathrm{CrO}_{4}\right)$ indicator was used to measure $\mathrm{Cl}^{-}$concentrations. The titrimetric technique, including a standard solution of sulphuric acid $\left(\mathrm{H}_{2} \mathrm{SO}_{4}\right)$ and methyl orange indicator, was used to detect $\mathrm{HCO}_{3}{ }^{-}$, and $\mathrm{CO}_{3}{ }^{2-}$ concentrations. Titration with silver nitrate was used to measure $\mathrm{Cl}^{-}$concentrations, and the titrimetric technique was used to detect $\mathrm{HCO}_{3}{ }^{-}$and $\mathrm{CO}_{3}{ }^{2-}$ concentrations. The concentrations of $\mathrm{SO}_{4}{ }^{2-}$ and $\mathrm{NO}_{3}{ }^{-}$were measured using the spectrophotometer instrument based on visible ultraviolet (UV) spectrum (DR/2040- Loveland, CO, USA). Several quality assurance techniques were performed during the examination of the water samples. In view of quality control, validation of the analytical procedures was carried out by proper calibration of instruments and checking their precision and linearity. Charge balance errors (CBE) were calculated after the field measurements were double-checked in the lab, and samples were tested in triplicate, with the average value given. The principle of neutrality states that the summation of cations should be equal to the summation of anions in $\mathrm{meq} / \mathrm{L}^{-1}$. The error in anion-cation balance is evaluated using Equation (1) [49]. Therefore, the $\mathrm{CBE}$ of all the analyzed samples were found within the recommended limit $\pm 5 \%$.

$$
\mathrm{CBE}=\frac{\sum \text { Cations }-\sum \text { Anions }}{\sum \text { Cations }+\sum \text { Anions }} \times 100
$$

Additionally, the analytical procedure's quality assurance was double-checked using Certified Reference Material (CRM) and blank method analysis.

\subsection{Indexing Method}

\subsubsection{Water Quality Indices (WQIs)}

The appropriateness of groundwater for both drinking and irrigation was assessed using the cited WQIs, which included DWQI, IWQI, TDS, PS, SAR, and RSC values (Table 1). An existing mathematical approach was used to turn the numerical impact of particular values and units of numerous water quality metrics into a single number [50,51], which is used to define the quality of water.

Table 1. Arithmetic rating method for calculation of drinking water quality index (DWQI).

\begin{tabular}{cccccc}
\hline $\begin{array}{c}\text { Physicochemical } \\
\text { Parameters }\end{array}$ & Unit & $\begin{array}{c}\text { WHO (2017) } \\
\mathbf{S}_{\mathbf{i}}\end{array}$ & Unit Weight $\mathbf{w}_{\mathbf{i}}$ & $\frac{\mathrm{C}_{\mathbf{i}}}{\mathrm{S}_{\mathbf{i}}} \times 100$ & $\mathbf{W}_{\mathbf{i}} \times\left(\frac{\mathrm{C}_{\mathbf{i}}}{\mathrm{S}_{\mathbf{i}}} \times 100\right)$ \\
\hline $\mathrm{pH}$ & - & 8.5 & 0.415 & 86.000 & 35.729 \\
$\mathrm{TDS}$ & $\mathrm{mg} / \mathrm{L}$ & 500 & 0.007 & 105.996 & 0.748 \\
$\mathrm{EC}$ & $\mu \mathrm{cm}$ & 1500 & 0.002 & 70.600 & 0.166 \\
$\mathrm{TH}$ & $\mathrm{mg} / \mathrm{L}$ & 500 & 0.007 & 60.944 & 0.430 \\
$\mathrm{~K}^{+}$ & $\mathrm{mg} / \mathrm{L}$ & 12 & 0.29 & 65.210 & 19.190 \\
$\mathrm{Na}^{+}$ & $\mathrm{mg} / \mathrm{L}$ & 200 & 0.017 & 33.388 & 0.589 \\
$\mathrm{Mg}^{2-}$ & $\mathrm{mg} / \mathrm{L}$ & 50 & 0.070 & 34.735 & 2.453 \\
$\mathrm{Ca}^{2+}$ & $\mathrm{mg} / \mathrm{L}$ & 75 & 0.047 & 124.540 & 0.864 \\
$\mathrm{Cl}^{-}$ & $\mathrm{mg} / \mathrm{L}$ & 250 & 0.014 & 43.076 & 1.012 \\
$\mathrm{SO}_{4}{ }^{2-}$ & $\mathrm{mg} / \mathrm{L}$ & 250 & 0.014 & 71.666 & 2.243 \\
$\mathrm{HCO}_{3}{ }^{2-}$ & $\mathrm{mg} / \mathrm{L}$ & 120 & 0.029 & 76.250 & 0.0345 \\
$\mathrm{CO}_{3}{ }^{-}$ & $\mathrm{mg} / \mathrm{L}$ & 350 & 0.0100 & 3.428 & 6.270 \\
$\mathrm{NO}_{3}{ }^{-}$ & $\mathrm{mg} / \mathrm{L}$ & 50 & 0.070 & 88.775 & \\
\hline & $\sum\left(\mathrm{S}_{\mathrm{i}}\right)$ & $\sum\left(\mathrm{w}_{\mathrm{i}}\right)=1$ & & $\sum_{\mathrm{i}=1}^{\mathrm{n}} \mathrm{W}_{\mathrm{i}} \times\left(\frac{\mathrm{C}_{\mathrm{i}}}{\mathrm{S}_{\mathrm{i}}} \times 100\right)$ \\
\hline
\end{tabular}




\subsubsection{Drinking Water Quality Index (DWQI)}

The DWQI values were calculated using the average concentrations of determinants of 30 parameters in Table 1 at each sample location according to Brown et al. [52]. For quality evaluation, the findings of laboratory analyses for all the samples collected were considered. The physicochemical criteria have been weighted according to their relative importance to overall water quality. The WQI depicts the complete water quality of each water component depending on a variety of water quality variables and their application in the environment according to Equation (2):

$$
\text { DWQI }=\sum_{i=1}^{n} W_{i} \times\left(\frac{C_{i}}{S_{i}} \times 100\right)
$$

$\mathrm{W}_{\mathrm{i}}$ represents each parameter's weight unit, and 13 physicochemical parameters were employed. The computed the concentration $\left(C_{i}\right)$ value and standard $\left(S_{i}\right)$ for each water parameter according to the following Equation (3):

$$
\mathrm{W}_{\mathrm{i}}=\frac{\mathrm{wi}}{\sum \mathrm{wi}}
$$

$\mathrm{w}_{\mathrm{i}}$ for each parameter is computed using the recommended standards [53] by Equation (4):

$$
\mathrm{w}_{\mathrm{i}}=\mathrm{K} / \mathrm{S}_{\mathrm{i}}
$$

where $\mathrm{K}$ denotes the constant of proportionality, which is calculated by using Equation (5):

$$
\mathrm{K}=\frac{1}{\sum \mathrm{S}_{\mathrm{i}}}
$$

To calculate the DWQI, each groundwater parameter $\left(\mathrm{w}_{\mathrm{i}}\right)$ is given a weight, and the relative weight is calculated $\left(\mathrm{W}_{\mathrm{i}}\right)$. Therefore, $\mathrm{W}_{\mathrm{i}}$ values were assigned for all physicochemical parameters in Table 1, while $\mathrm{w}_{\mathrm{i}}$ was calculated using Equation (4). The computed values of the standards, unit weights $\left(\mathrm{w}_{\mathrm{i}}\right)$, and arithmetic weights $\left(\mathrm{W}_{\mathrm{i}}\right)$ for the water parameters are illustrated in Table 1.

\subsubsection{Irrigation Water Quality Index (IWQI)}

The IWQI was estimated using water quality metrics such as EC, SAR, $\mathrm{Na}^{+}, \mathrm{Cl}^{-}$, and $\mathrm{HCO}_{3}{ }^{2-}$ [54-56], according to the following Equation (6):

$$
\mathrm{IWQI}=\sum_{\mathrm{i}=1}^{\mathrm{n}} \mathrm{Q}_{\mathrm{i}} \mathrm{W}_{\mathrm{i}}
$$

Depending on each value of physicochemical parameter, the aggregation weights $\left(\mathrm{W}_{\mathrm{i}}\right)$ and value of water quality parameter $\left(\mathrm{Q}_{\mathrm{i}}\right)$ were calculated using the criteria established by Ayers and Westcot [57] according to Equation (7):

$$
\mathrm{Q}_{\mathrm{i}}=\mathrm{Q}_{\max }-\left(\frac{\left[\left(\mathrm{X}_{\mathrm{ij}}-\mathrm{X}_{\mathrm{inf}}\right) \times \mathrm{Q}_{\mathrm{imap}}\right]}{\mathrm{X}_{\mathrm{amp}}}\right)
$$

where $Q_{\max }$ is the greatest $Q_{i}$ value for each class, $X_{i j}$ is the observed value of each physicochemical parameter, and $X_{\text {inf }}$ is the class's lower limit value. $Q_{i m a p}$ and $X_{a m p}$ denote the class amplitude and class amplitude to which the parameter belongs, respectively.

Finally, the $W_{i}$ values were normalized, and their final total equaled one using the following Equation (8):

$$
W_{i}=\frac{\sum_{j=1}^{k} F_{j} A_{i j}}{\sum_{j=1}^{k} \sum_{i=1}^{n} F_{j} A_{i j}}
$$


where Wi and F are the comparative weights of the IWQI physicochemical characteristics, and component $i$ is a constant value; The parameter $i$ that can be described by factor $j$ is denoted by $\mathrm{A}_{\mathrm{ij}}$. The number of physicochemical parameters used in the IWQI ranges from 1 to $\mathrm{n}$, while the number of factors chosen in the IWQI ranges from 1 to $\mathrm{k}$.

\subsubsection{Total Dissolves Solids (TDS)}

The TDS is an important parameter to express the status of contaminants present in the groundwater, estimated in mg/L [57], according to Equation (9):

$$
\mathrm{TDS}=\left(\mathrm{Ca}^{2+}+\mathrm{Mg}^{2+}+\mathrm{Na}^{+}+\mathrm{K}^{+}+\mathrm{Cl}^{-}+\mathrm{SO}_{4}{ }^{2-}+\mathrm{HCO}_{3}{ }^{2-}+\mathrm{CO}_{3}{ }^{-}+\mathrm{NO}_{3}{ }^{-}\right)
$$

\subsubsection{Potential Salinity (PS)}

The PS is another irrigation quality index that was estimated in milliequivalents per liter [58] according to Equation (10):

$$
\mathrm{PS}=\mathrm{Cl}^{-}+\left(\mathrm{SO}_{4}^{2-} / 2\right)
$$

\subsubsection{Sodium Adsorption Ratio (SAR)}

The SAR is an important irrigation quality index, which also evaluates the contents of cations expressed in milliequivalents per liter [59] according to Equation (11):

$$
\mathrm{SAR}=\left(\frac{\mathrm{Na}^{+}}{\sqrt{\left(\mathrm{Ca}^{2+}+\mathrm{Mg}^{2+}\right) / 2}}\right) \times 100
$$

\subsubsection{Residual Sodium Carbonate (RSC)}

The RSC is another index to assess the suitability of water for irrigation, which is expressed as Equation (12) [60,61].

$$
\mathrm{RSC}=\left(\mathrm{HCO}_{3}{ }^{2-}+\mathrm{CO}_{3}^{-}\right)-\left(\mathrm{Ca}^{2+}+\mathrm{Mg}^{2+}\right)
$$

\subsection{Partial Least-Square Regression (PLSR) and Multiple Linear Regression (MLR)}

In this work, PLSR models were used to evaluate the WQIS, DWQI, IWQI, TDS, SAR, PS, and RSC. PLSR models of six WQIs were constructed using version 10.2 of the unscramble X program (CAMO Software AS, Oslo, Norway). The PLSR model used physicochemical parameters in Table 1 as the input parameter (independent parameters) to predict the DWQI as output parameters (dependent v parameters). The PLSR model also used chemical parameters in Table 1 as the input parameter (independent parameters) to predict the IWQI, TDS, SAR, PS, and RSC as output parameters (dependent parameters). The input variables were linked to the output variables using PLSR and leave-one-out crossvalidation (LOOCV). In PLSR analysis, selecting the correct number of latent variables (LVs) to represent the calibration data without overfitting or underfitting is critical. Random 10 -fold cross-validation was carried out on the datasets to improve the robustness of the results.

Four criteria were used to evaluate the PLSR's performance in predicting the six WQIs for calibration (Cal.) and validation (Val.) models.

(1) $R^{2}$ coefficient;

$$
\mathrm{R}^{2}=1-\frac{\sum_{\mathrm{i}=1}^{\mathrm{n}}\left(\mathrm{WQIso}_{\mathrm{i}}-\mathrm{WQIs}_{\mathrm{fi}}\right)^{2}}{\sum_{\mathrm{i}=1}^{\mathrm{n}}\left(\mathrm{PIso}_{\mathrm{i}}\right)^{2}}
$$

(2) root mean square error (RMSE); 


$$
\text { RMSE }=\sqrt{\frac{\sum_{i=1}^{n}\left(\text { WQIso }_{i}-\mathrm{WQIs}_{\mathrm{fi}}\right)^{2}}{\mathrm{n}}}
$$

(3) mean absolute deviation (MAD);

$$
\mathrm{MAD}=\frac{\sum_{\mathrm{i}=1}^{\mathrm{n}}\left|\mathrm{WQIso}_{\mathrm{i}}-\mathrm{WQIs}_{\mathrm{fi}}\right|}{\mathrm{n}}
$$

(4) Accuracy (ACC) of the models

$$
\mathrm{Acc}=1-\operatorname{abs}\left(\text { mean } \frac{\text { WQIs }_{\mathrm{fi}_{\mathrm{i}}}-\mathrm{WQIso}_{\mathrm{i}}}{\text { WQIso }_{\mathrm{i}}}\right)
$$

e measured value is $\mathrm{WQIso}_{i}$, the number of data points is $n$, and the predicted value is WQIs $s_{\mathrm{fi}}$. The best models were chosen for their low RMSE and MAD, as well as their high $\mathrm{R}^{2}$ and Acc.

\subsection{Data Analysis and Graphical Approach}

SPSS version 22 was used to construct a statistical analysis (range, mean, standard deviation) of the physical and chemical characteristics (SPSS Inc., Chicago, IL, USA). Different models for hydrochemical facies evolution, such as the Piper, Chadah, Gibbs, and hydrochemical facies evolution diagrams [62-65], have been proposed utilizing Geochemist's Software package 12.0 to determine water types, geochemistry mechanisms, and major water chemical control factors. To generate zoning maps for water quality indicators assessed in the present study, GIS version 10.0 was utilized. The DWQI and IWQI maps were constructed by combining datasets for physicochemical metrics because of geo-statistical data analysis, which included the use of inverse distance weighted (IDW) kriging. This method is a component enhancement for the spatial analytical technique in GIS. In addition, the CA and PCA were created by dividing a set of variables by their maximum values using PAST software (V. 4.0) in order to understand the relationships and variance between the physicochemical determinants.

\section{Results and Discussion}

\subsection{Physicochemical Parameters}

Physical and chemical metrics are useful benchmarks to understand the status of water geochemistry and associated regulatory processes, and therefore play a crucial role in the evolution of water quality. Table 2 contains statistical descriptions of the physical and chemical characteristics in the analyzed groundwater points (min., max., mean, and standard deviation).

\begin{tabular}{|c|c|c|c|c|c|c|c|c|c|c|c|c|c|c|}
\hline & & \multicolumn{13}{|c|}{ Makkah Al-Mukarramah Province, KSA $(n=59)$} \\
\hline & $\mathrm{T}^{\circ} \mathrm{C}$ & $\mathrm{pH}$ & EC & TDS & TH & $\mathrm{K}^{+}$ & $\mathrm{Na}^{+}$ & $\mathrm{Mg}^{2+}$ & $\mathrm{Ca}^{2+}$ & $\mathrm{Cl}^{-}$ & $\mathrm{SO}_{4}{ }^{2-}$ & $\mathrm{HCO}_{3}{ }^{2-}$ & $\mathrm{CO}_{3}^{-}$ & $\mathrm{NO}_{3}^{-}$ \\
\hline Min & 30.00 & 6.99 & 553.00 & 226.90 & 44.10 & 0.99 & 43.64 & 4.11 & 10.91 & 70.53 & 30.00 & 12.20 & 0.00 & 0.01 \\
\hline $\operatorname{Max}$ & 32.00 & 8.39 & $25,000.00$ & $18,518.30$ & 6025.50 & 79.03 & 4602.75 & 575.27 & 1995.80 & 7271.03 & 5180.27 & 274.50 & 24.00 & 475.44 \\
\hline Mean & 30.60 & 7.74 & 4217.20 & 2572.30 & 1188.90 & 13.87 & 441.93 & 90.56 & 327.25 & 926.22 & 692.35 & 146.18 & 7.01 & 57.27 \\
\hline $\mathrm{SD}$ & 0.75 & 0.33 & 4595.60 & 3247.10 & 1209.10 & 13.35 & 729.02 & 108.44 & 333.83 & 1450.50 & 788.69 & 51.56 & 8.19 & 84.55 \\
\hline
\end{tabular}

Table 2. Statistical description of several physical and chemical parameters in the collected groundwater wells.

All physical and chemical parameters are stated in $\mathrm{mg} / \mathrm{L}$ excluding temperature $\left(\mathrm{T}^{\circ} \mathrm{C}\right), \mathrm{pH}$ and $\mathrm{EC}(\mu \mathrm{s} / \mathrm{cm})$.

The data analysis of physicochemical characteristics for groundwater samples obtained showed that $\mathrm{pH}$ values varied between 6.99 and 8.39 by a mean of 7.74 , which indicated that the groundwater was slightly alkaline. Groundwater temperatures ranged from 30.00 to $32.00{ }^{\circ} \mathrm{C}$, depending on the depths to water surface in wells (Figure 3). The EC readings ranged from 553 to $25,000 \mu \mathrm{s} / \mathrm{cm}$, with an average value of $4217.20 \mu \mathrm{s} / \mathrm{cm}$. TDS levels varied from 226.90 to $18,518.30 \mathrm{mg} / \mathrm{L}$, with a mean value of $2572.3 \mathrm{mg} / \mathrm{L}$, which reflected brack- 
ish groundwater type. The ionic content of $\mathrm{K}^{+}, \mathrm{Na}^{2+}, \mathrm{Mg}^{+2}, \mathrm{Ca}^{+2}, \mathrm{Cl}^{-}, \mathrm{SO}_{4}{ }^{2-}, \mathrm{HCO}_{3}{ }^{2-}$, $\mathrm{CO}_{3}{ }^{-}$and $\mathrm{NO}_{3}{ }^{-}$displayed mean values of $13.87,441.93,90.56,327.25,926.22,692.35,146.18$, 7.01 and $57.27 \mathrm{mg} / \mathrm{L}$, respectively (Table 2). Therefore, the average values of ions presented sequences of $\mathrm{Na}^{2+}>\mathrm{Ca}^{+2}>\mathrm{Mg}^{+2}>\mathrm{K}^{+}$, and $\mathrm{Cl}^{-}>\mathrm{SO}_{4}{ }^{2-}>\mathrm{HCO}_{3}{ }^{2-}>\mathrm{NO}_{3}{ }^{-}>\mathrm{CO}_{3}{ }^{-}$, respectively. These values indicated that $\mathrm{Na}^{2+}$ was the dominant cation and $\mathrm{Cl}^{-}$was the dominant anion in the collected water samples.

\subsection{Geochemical Facies and Controlling Mechanisms}

Hydrochemical data were evaluated using imitative techniques to better understand the numerous geochemical processes that regulate groundwater quality. For identifying the geochemical facies and types of groundwater in the study area, Piper's trilinear diagram was used to determine the prevailing cations and anions in meq/L of the collected samples (Figure 4a). The chemical properties of the examined groundwater samples revealed that the hydrochemical facies were $\mathrm{Ca}-\mathrm{HCO}_{3}, \mathrm{Na}-\mathrm{Cl}$, mixed $\mathrm{Ca}-\mathrm{Mg}-\mathrm{Cl}-\mathrm{SO}_{4}$, and $\mathrm{Na}-\mathrm{Ca}-\mathrm{HCO}_{3}$. Chadah's arrangement is also used to determine the hydrochemical mechanisms and groundwater types (Figure 4 b). The groundwater samples were scattered in fields 2 and 3 , which demonstrated a reverse ion exchange process as a result of cation exchange process in the groundwater system and mixing with saline water, especially downstream of Wadi Fatimah. As a result, $\mathrm{Ca}^{2+}$ in the groundwater was replaced by $\mathrm{Na}^{+}$in the aquifer, which reflected a decrease in $\mathrm{Ca}^{2+}$ concentration and increase in $\mathrm{Na}^{+}$concentration, indicating that groundwater in the study area was affected by the cation exchange process.

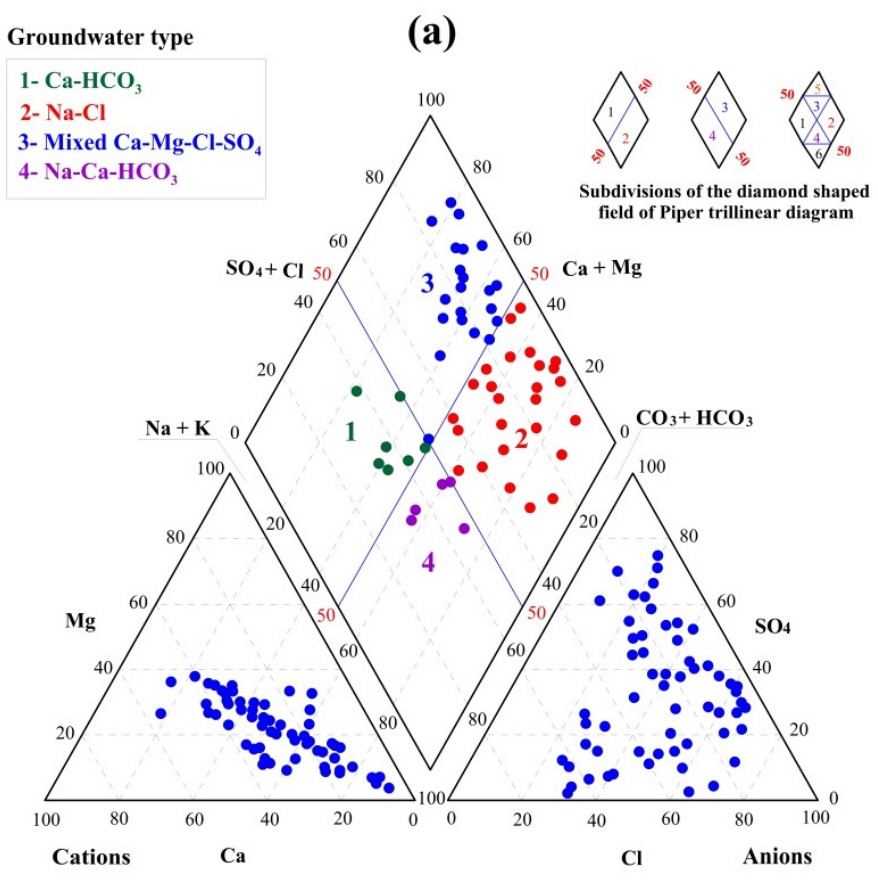

(b)

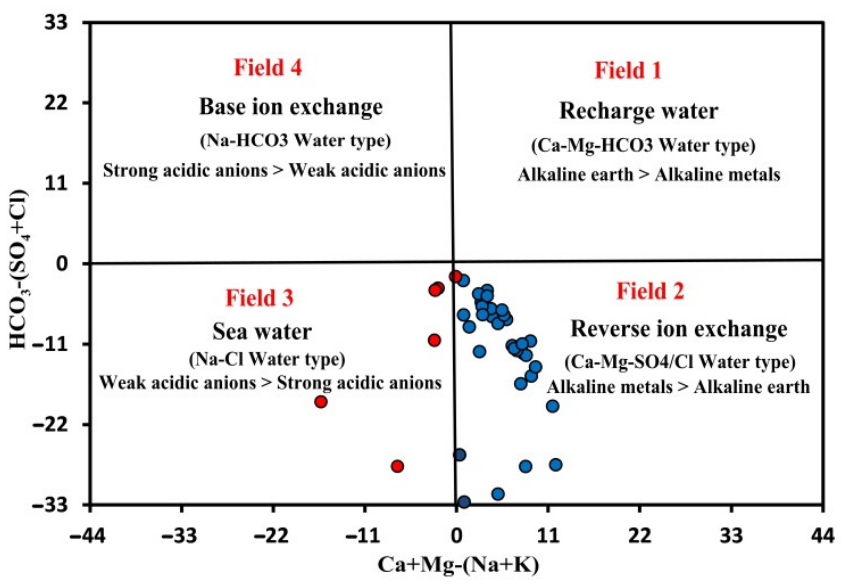

Figure 4. Geochemical facies and water type: (a) Piper diagram and (b) Chadha diagram.

The effects of the weathering process and aquifer matrix considerably alter the chemical composition of groundwater. The Gibbs diagram is frequently applied to create the link between the water component and the aquifer matrix [64] (Gibbs, 1970). The key regulating processes that determine groundwater geochemistry are identified by Gibb's diagram through displaying TDS vs. $(\mathrm{Na}+\mathrm{K}) /(\mathrm{Na}+\mathrm{K}+\mathrm{Ca})$ and $\mathrm{Cl} /\left(\mathrm{Cl}+\mathrm{HCO}_{3}\right)$. As shown in a plotting of chemical data on the Gibbs diagram, groundwater samples were spread in the evaporation, weathering, and rock-water interaction fields (Figure 5a), which are significant processes regulating groundwater chemistry and quality. HFE plot findings demonstrated dissolving of evaporite from salt marches in aquifer materials, which are high in sulphate and chloride (Figure 5b) content. The majority of samples representing mixed 
water (Ca-Mg- $\mathrm{HCO}_{3}$ and $\mathrm{Na}-\mathrm{Cl}$ ) revealed high calcium and sodium content, as a result of clays in the Quaternary aquifer, and the volcaniclastic sequence of the Fatimah Basin was found to be rich in $\mathrm{Na}^{+}[66]$ and the groundwater in $\mathrm{Ca}^{2+}$. Obviously, most groundwater samples scattered in the intrusion area indicated that intrusion is a significant process in the formation of dissolved solutes for groundwater samples. Moreover, evaporation is the most significant mechanism for groundwater and soil salinization in areas with shallow groundwater depth as well as high evaporation rate [67]. Brines from evaporate minerals dissolve in the recharge zone in closed basins, enhancing the salinity of the groundwater over time. In closed basins, salinity levels increase from the inflow area to the outflow area as a result of over-pumping and a negative water balance, converting the hydrochemical facies from $\mathrm{Ca}-\mathrm{HCO}_{3}$ to $\mathrm{Na}-\mathrm{Cl}$ [68]. The chemical composition changes are mostly induced via groundwater flow direction and reactions [69].

(a)
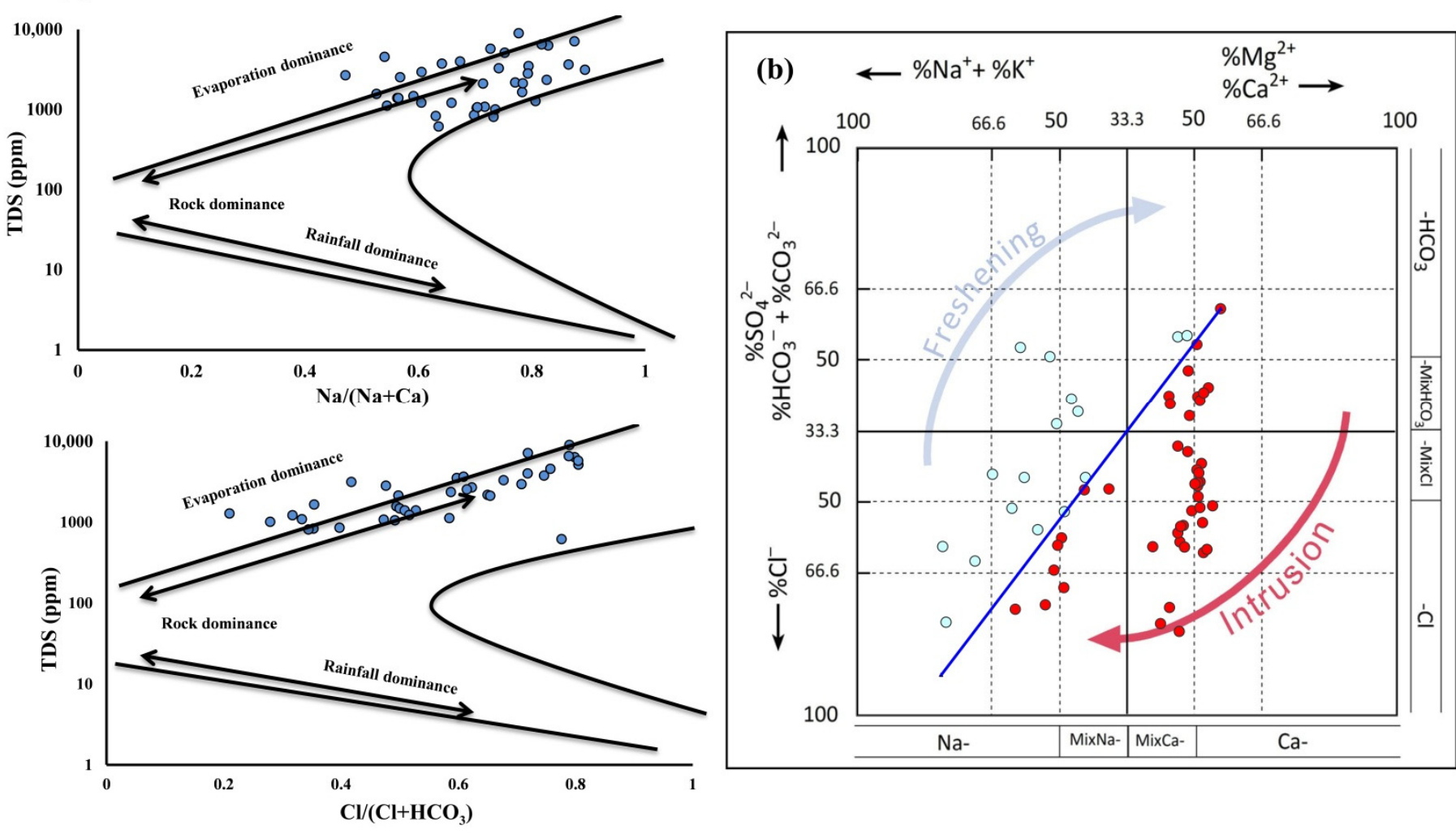

Figure 5. Geochemical controlling mechanisms: (a) Gibbs diagram and (b) Hydrochemical facies evolution diagram (HFE).

\subsection{Water Quality Indices}

Table 3 showed the statistical analysis and categorization of several WQIs in this study, which included DWQI, IWQI, TDS, PS, SAR, and RSC. In addition, GIS-Zoning maps for each index were used to display and examine the quality of water in the investigated area for potable and agricultural purposes (Figures 6-8). 
Table 3. Statistical analyses and classification of the different water quality indices (WQIs).

\begin{tabular}{|c|c|c|c|c|c|c|c|}
\hline \multirow{2}{*}{$\begin{array}{l}\text { Water Quality } \\
\text { Indices (WQIs) }\end{array}$} & \multicolumn{4}{|c|}{ Sample Range } & \multirow{2}{*}{ Range } & \multirow{2}{*}{ Water Category } & \multirow{2}{*}{$\begin{array}{l}\text { Number of } \\
\text { Samples (\%) }\end{array}$} \\
\hline & Min. & Max. & Mean & SD & & & \\
\hline \multirow{5}{*}{$\begin{array}{l}\text { Drinking water } \\
\text { quality (DWQI) }\end{array}$} & 23.29 & 545.53 & 118.68 & 88.28 & $0-25$ & Excellent & $1(2 \%)$ \\
\hline & & & & & $26-50$ & Good & $2(3 \%)$ \\
\hline & & & & & $51-75$ & Poor & $10(17 \%)$ \\
\hline & & & & & $76-100$ & Very poor & $19(32 \%)$ \\
\hline & & & & & $>100$ & Unsuitable & $27(46 \%)$ \\
\hline \multirow{5}{*}{$\begin{array}{l}\text { Irrigation water } \\
\text { quality index } \\
\text { (IWQI) }\end{array}$} & 19.42 & 95.93 & 64.07 & 20.42 & $85-100$ & No restriction & $15(25.5 \%)$ \\
\hline & & & & & $70-85$ & Low restriction & $12(20.5 \%)$ \\
\hline & & & & & $55-70$ & Moderate restriction & $5(8.5 \%)$ \\
\hline & & & & & $40-55$ & High restriction & $22(37 \%)$ \\
\hline & & & & & $0-40$ & Serve restriction & $5(8.5 \%)$ \\
\hline \multirow{3}{*}{$\begin{array}{l}\text { Total dissolved } \\
\text { solids (TDS) }\end{array}$} & 226.90 & $18,518.32$ & 2572.30 & 3247.14 & $<700$ & No restriction & $12(20 \%)$ \\
\hline & & & & & $700-3000$ & Slight to moderate restriction & $33(56 \%)$ \\
\hline & & & & & $>3000$ & Serve restriction & $14(24 \%)$ \\
\hline \multirow{3}{*}{$\begin{array}{l}\text { Potential salinity } \\
\text { (PS) }\end{array}$} & 3.03 & 258.96 & 33.32 & 48.17 & $<3$ & Excellent to good & $0(0.0 \%)$ \\
\hline & & & & & 3 to 5 & Good to Injurious & $8(14 \%)$ \\
\hline & & & & & $>5$ & Injurious to Unsatisfactory & $51(86 \%)$ \\
\hline \multirow{4}{*}{$\begin{array}{l}\text { Sodium adsorption } \\
\text { ratio (SAR) }\end{array}$} & 1.109 & 31.00 & 4.84 & 4.86 & $2-10$ & Excellent & $54(92 \%)$ \\
\hline & & & & & $10-18$ & Good & $3(5 \%)$ \\
\hline & & & & & $18-26$ & Doubtful or Fairly poor & $1(1.5 \%)$ \\
\hline & & & & & $>26$ & Unsuitable & $1(1.5 \%)$ \\
\hline \multirow{3}{*}{$\begin{array}{l}\text { Residual Sodium } \\
\text { Carbonate (RSC) }\end{array}$} & -118.91 & -0.40 & -21.14 & 24.33 & $<1.25$ & Safe & $59(100 \%)$ \\
\hline & & & & & $1.25-2.5$ & Marginal & $0(0.0 \%)$ \\
\hline & & & & & $>2.5$ & Unsuitable & $0(0.0 \%)$ \\
\hline
\end{tabular}

All WQIs are estimated in meq/L except DWQI, IWQI and TDS in mg/L. Min.: Minimum, Max.: Maximum, SD: Standard deviation.

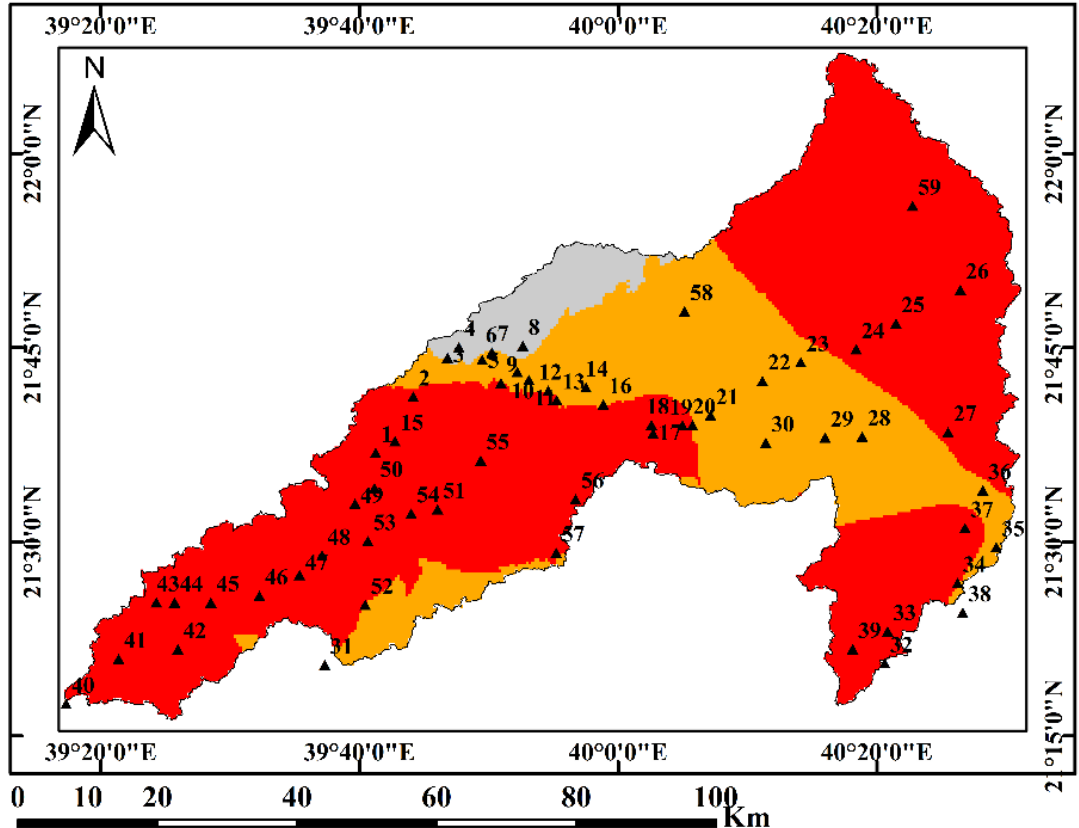

63.4 - 75 (Poor)

$75.1-100$ (Very poor)

100.1 - 391 (Unsuitable for drinking)

Figure 6. Spatial distribution map of DWQI in the study area. 


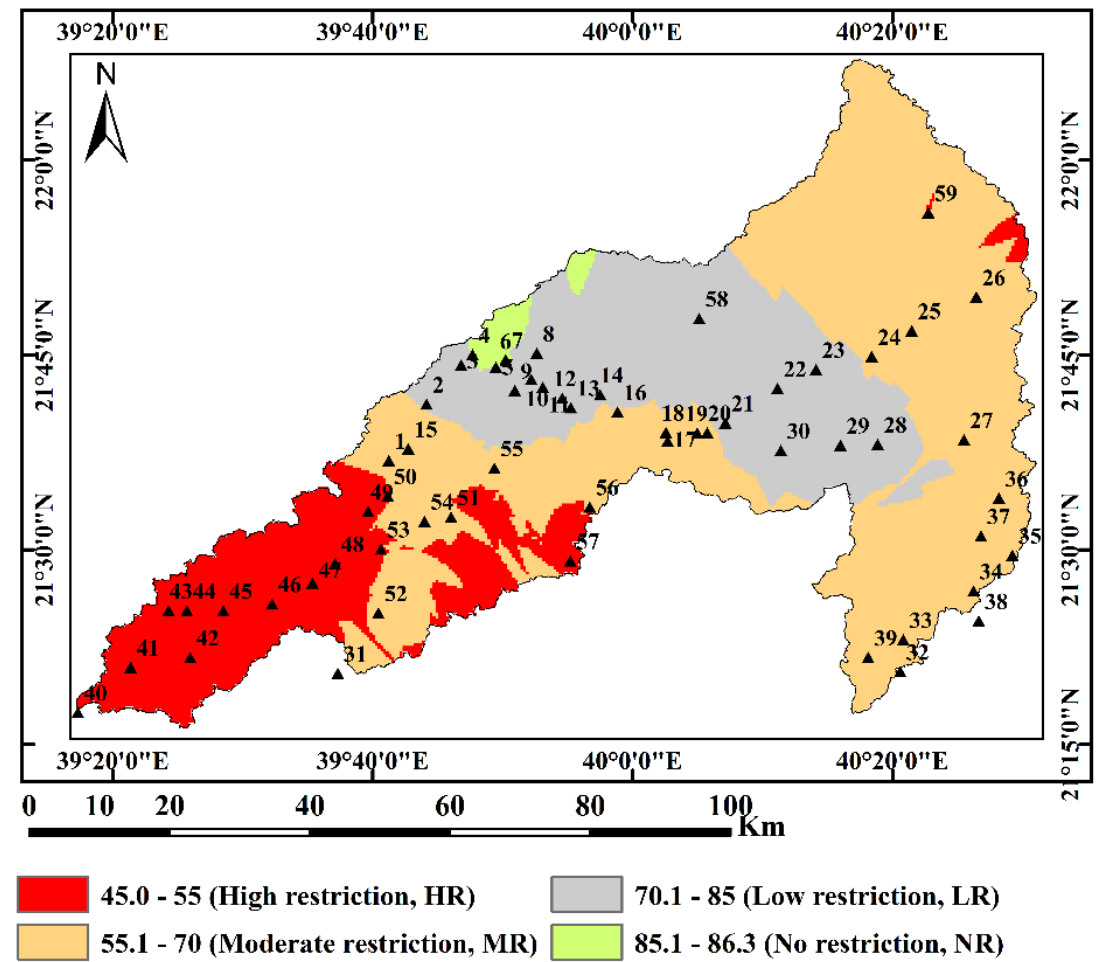

Figure 7. Spatial distribution map of IWQI in the study area.

\subsubsection{Drinking Water Quality Index (DWQI)}

The DWQI model was applied to determine groundwater quality, which is classified based on the purity level of routinely detected water quality parameters according to Equation (1). The DWQI was developed to measure the acceptability of groundwater for drinking. The computed value of DWQI in the obtained groundwater samples is shown in Table 4, ranging from 23.29 to 545.53, with an average of around 118.68. According to DWQI categorization (Table 3), approximately $2 \%$ of groundwater was categorized as excellent, $3 \%$ as good, $17 \%$ as poor, $32 \%$ as extremely poor, and $46 \%$ as unfit for drinking. The DWQI distribution map (Figure 6) indicates that most of the groundwater samples cannot be utilized for safe drinking due to evaporation, rock-water interaction, and reverse ion exchange process in the north-eastern parts as well as saltwater intrusion downstream of Wadi Fatimah toward the Red Sea.

Table 4. Results of calibration $\left(R^{2}\right.$ cal, $R M S E_{C}, M A D_{c}$, and $\left.A c_{c}\right)$, and ten-fold cross-validation $\left(R^{2}{ }_{v a l}\right.$, $\mathrm{RMSE}_{\mathrm{V}}, \mathrm{MAD}_{\mathrm{v}}$, and $\mathrm{Acc}_{\mathrm{v}}$ ): PLSR models of the relationships between several physicochemical parameters and drinking water quality index (DWQI), irrigation water quality index (IWQI), total dissolved solids, potential salinity (PS), sodium absorption ratio (SAR), and residual sodium carbonate (RSC). ${ }^{* * *}: p<0.001$.

\begin{tabular}{ccccccccccc}
\hline & \multirow{2}{*}{$\begin{array}{c}\text { Water Quality } \\
\text { Indices }\end{array}$} & LVs & \multicolumn{4}{c}{ Calibration } & \multicolumn{4}{c}{ Validation } \\
\cline { 4 - 10 } & & & $\mathbf{R}_{\text {cal }}$ & $\mathbf{R M S E}_{\mathbf{c}}$ & $\mathbf{M A D}_{\mathbf{c}}$ & $\mathbf{A C C}_{\mathbf{c}}$ & $\mathbf{R}_{\mathbf{v a l}}$ & $\mathbf{R M S E}_{\mathbf{v}}$ & $\mathbf{M A D}_{\mathbf{v}}$ & $\mathbf{A C C}_{\mathbf{v}}$ \\
\hline \multirow{3}{*}{ PLSR } & 9 & $0.992^{* * *}$ & 7.356 & 6.323 & 0.991 & $0.987^{* * *}$ & 10.030 & 7.686 & 0.989 \\
& IWQI & 4 & $0.905^{* * *}$ & 10.516 & 5.781 & 0.999 & $0.848^{* * *}$ & 13.680 & 6.331 & 0.984 \\
& TDS & 2 & $0.999^{* * *}$ & 58.920 & 21.147 & 0.981 & $0.999^{* * *}$ & 71.985 & 26.538 & 0.980 \\
& PS & 1 & $0.989^{* * *}$ & 0.982 & 0.279 & 0.998 & $0.999^{* * *}$ & 1.494 & 0.273 & 0.985 \\
& SAR & 2 & $0.919^{* * *}$ & 1.370 & 0.811 & 0.824 & $0.861^{* * *}$ & 1.838 & 0.814 & 0.817 \\
& RSC & 2 & $0.999^{* * *}$ & 0.762 & 0.427 & 0.962 & $0.998^{* * *}$ & 0.874 & 0.448 & 0.924 \\
\hline
\end{tabular}



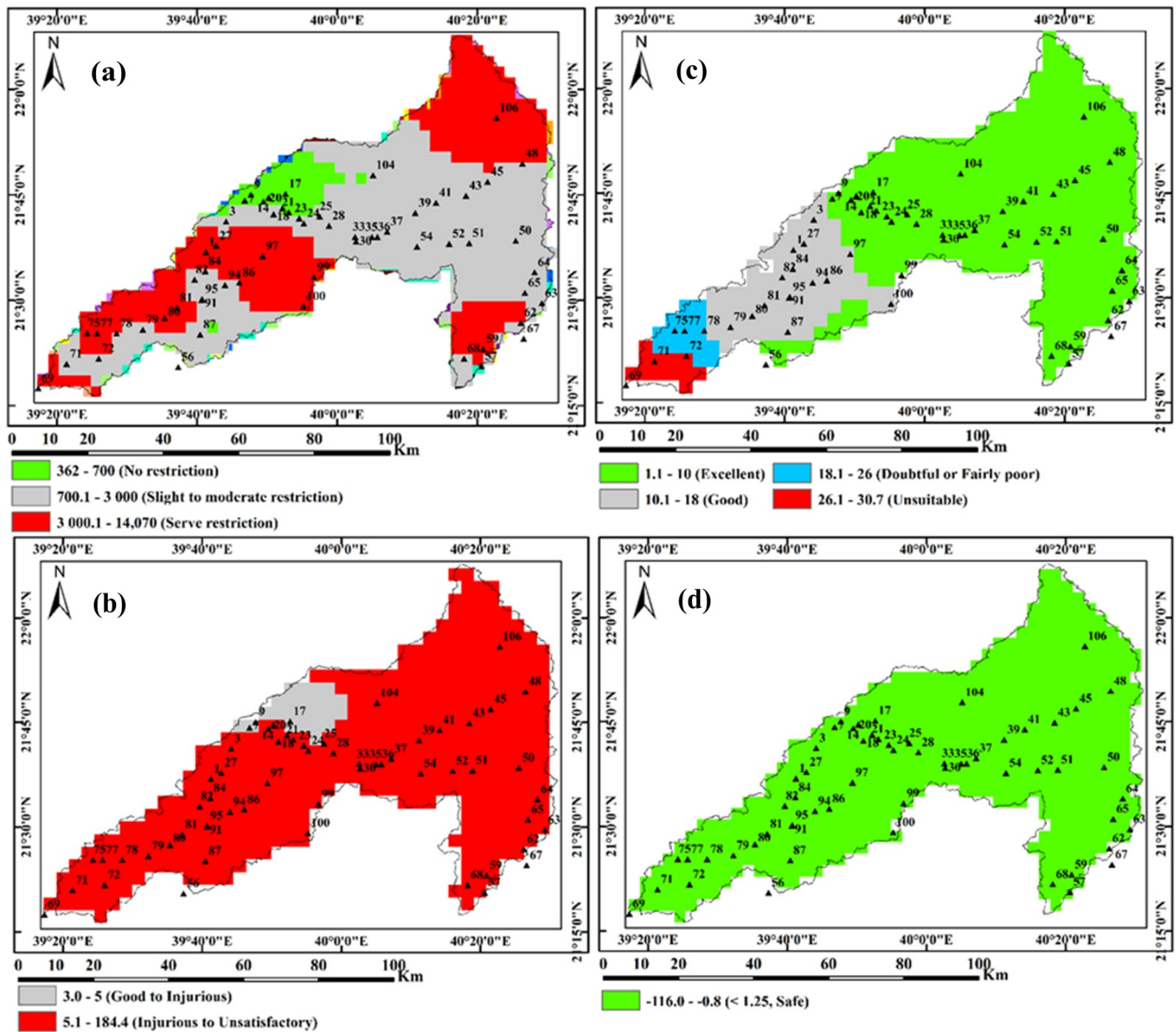

Figure 8. Spatial distribution maps of irrigation water quality indices: (a) total dissolved solids (TDS), (b) potential salinity (PS), (c) sodium adsorption ratio (SAR), and (d) residual sodium carbonate (RSC).

\subsubsection{Irrigation Water Quality Index (IWQI)}

The IWQI was recognized as one of the most essential methods for urban planners to analyze irrigated water quality since it provided a clear categorization of water quality based on its effect on soil and plants [70]. According to the results of IWQI classification (Table 3 and Figure 7), about $8.5 \%$ of the examined groundwater samples fall in the severe restriction range, which may be utilized to irrigate high salt sensitivity crops. While $37 \%$ of the wells studied fall in the high restriction category, which can be utilized to irrigate moderate to high salinity tolerance crops in loose soil with no compacted layers and a specific frequency of irrigation (EC > $2000 \mathrm{~S} / \mathrm{cm}$ and SAR $>7$ ), approximately $8.5 \%$ of the tested wells fall in moderate limitation, which may be utilized to irrigate moderate salinity tolerance crops and are suggested for medium to high permeable soils with respect to leaching processes. Furthermore, $20.5 \%$ of the samples fall in the low restriction group, which suggests preventing salinity tolerance crops with respect to irrigated soil characteristics, permeability, and soil sodicity hazards. Lastly, $25.5 \%$ of wells were detected with no limitation range and may be used for most soils with potentially low harmful effects 
of salinity and sodicity on most crops [57]. Figure 7 showed the spatial distribution of different water quality types for irrigation with respect to IWQI, where the quality of the groundwater for agriculture decreased greatly from the northeast to southwest toward the Red Sea with the same groundwater flow direction.

\subsubsection{Total Dissolved Solids (TDS)}

TDS is commonly used to determine the salinity of groundwater wells, which in this case ranged from 226.90 to $18,518.32$ with an average of 2572.30. Table 3 and Figure 8a show the categorization of collected groundwater wells according to salinity levels. TDS values indicated that about $20 \%$ of the groundwater wells have salinity levels less than $700 \mathrm{mg} / \mathrm{L}$, which ensures no restriction for irrigation; approximately $56 \%$ have salinity levels ranging from 700 to $3000 \mathrm{mg} / \mathrm{L}$, which mandates slight to moderate restriction for agriculture; and the remaining $24 \%$ have a salinity level of more than $3000 \mathrm{mg} / \mathrm{L}$, making it unsuitable and highly restrictive for irrigation [71-73], as presented in Table 3. Figure 8a showed the spatial distribution of groundwater quality for agriculture with respect to salinity hazard in the investigated area. As a result, the use of groundwater for irrigation becomes more restricted downstream of Wadi Fatimah.

\subsubsection{Potential Salinity (PS)}

The PS, computed as the totality of $\mathrm{Cl}^{-}$and half of $\mathrm{SO}_{4}{ }^{2-}$, is also an essential metric for measuring the appropriateness of groundwater for irrigation. The values of PS varied from 3.03 to 258.96 with an average of 33.32 (Table 3). Approximately $14 \%$ of the total samples were categorized as good to injurious, while $86 \%$ of total samples were categorized as injurious to unsatisfactory for agriculture. Figure $8 \mathrm{~b}$ showed spatial distribution of groundwater quality for agriculture with respect to PS, where high PS was observed in most parts of the investigated area (Figure $8 b$ ).

\subsubsection{Sodium Absorption Ratio (SAR)}

SAR is a ratio of the primary alkaline and earth alkaline cations available in water to crops. It is a useful measurement for evaluating the acceptability of irrigated water depending on sodium risk [74,75], and is more strongly connected to the exchangeable sodium percentages of the soil [76]. The use of high-sodium water for agriculture may enhance the interchange of sodium levels in the soil, reducing soil permeability and soil structure [77]. Soil treatment may be required in agriculture, where the water has a high SAR value to minimize long-term soil deterioration because the $\mathrm{Ca}^{2+}$ and $\mathrm{Mg}^{2+}$ in the soil may be displaced by sodium in the water. It may also result in decreased soil penetration and permeability to water, which may be hazardous for crop productivity. The water quality categorization for irrigation according to SAR (Table 3) indicated that the SAR value ranged from 1.109 to 31.0 with an average of 4.84 . Table 3 showed that around $92 \%$ of the wells were found in the range of excellent category and about $5 \%$ in the range of good category, thereby suitable for irrigation purposes with no alkali hazard to the crops. The rest of the samples, about 3\%, ranged from fairly poor to unsuitable for irrigation. The SAR spatial distribution map (Figure 8c) shows that groundwater quality for irrigation decreases gradually from the northeast to southwest direction toward the Red Sea, compatible with the direction of groundwater flow in the area.

\subsubsection{Residual Sodium Carbonate (RSC)}

Alkalinity concentration of water is a significant factor in evaluating its appropriateness for irrigation [78]. The term 'Residual Sodium Carbonate' (RSC) is used when alkalinity contents exceed alkaline earth metals $\left(\mathrm{Ca}^{2+}\right.$ and $\left.\mathrm{Mg}^{2+}\right)$ and shows the harmful influence of alkalinity on irrigation water quality $[79,80]$. The RSC of groundwater wells varied from -118.91 to -0.40 with an average of -21.14 (Table 3 ). Results showed that all samples had RSC values of less than 1.25 , indicating minimal alkalinity hazard and 
the ability to be utilized safely for agriculture with no development of alkalinity hazard (Figure 8d).

\subsection{Multivariate Statistical Analysis}

The CA and PCA were used in multivariate statistical analysis to detect the sources accountable for changes in the quality of water resource by combining primary variables into a new set of variables. CA results for major physical and chemical parameters indicated three kinds of clustering (Figure 9a), with EC and TDS in the same cluster (Cluster 1); $\mathrm{Na}^{+}$, $\mathrm{SO}_{4}{ }^{2-}$, and $\mathrm{Cl}^{-}$in another cluster (Cluster II); and $\mathrm{pH}, \mathrm{K}^{+}, \mathrm{Ca}^{2+}, \mathrm{Mg}^{2+}, \mathrm{HCO}_{3}{ }^{2-}, \mathrm{CO}_{3}{ }^{2-}$, and $\mathrm{NO}_{3}{ }^{-}$in a different cluster (Cluster III). According to the $\mathrm{CA}$ of major physicochemical parameters, groundwater in the study area was categorized into $\mathrm{Na}^{+}, \mathrm{Ca}^{2+}, \mathrm{Mg}^{2+}$, and $\mathrm{K}^{+}$as dominant cations, and $\mathrm{Cl}^{-}, \mathrm{SO}_{4}{ }^{2-}$, and $\mathrm{HCO}_{3}{ }^{2-}$ as dominant anions respectively (Figure 9a). According to the CA results, the high content of $\mathrm{Na}^{+}$and $\mathrm{Ca}^{2+}$ suggested rock-water interaction that revealed the release of $\mathrm{Ca}^{2+}$ by the weathering of silicate minerals, while the high concentration of $\mathrm{Cl}^{-}$and $\mathrm{SO}_{4}{ }^{2-}$ revealed clay interaction with aquifer matrix and saltwater intrusion. The distribution of physicochemical parameters in the groundwater resources revealed the second and final stages of water evolution, which reflects deterioration in groundwater quality in the investigated area as a result of evaporation process, saltwater intrusion, weathering process, and rock-water interaction. These results are in agreement with the water facies presented by Piper plotting due to the effects of evaporation, weathering, and rock-water interactions stated in the Gibbs and Chadha diagrams.

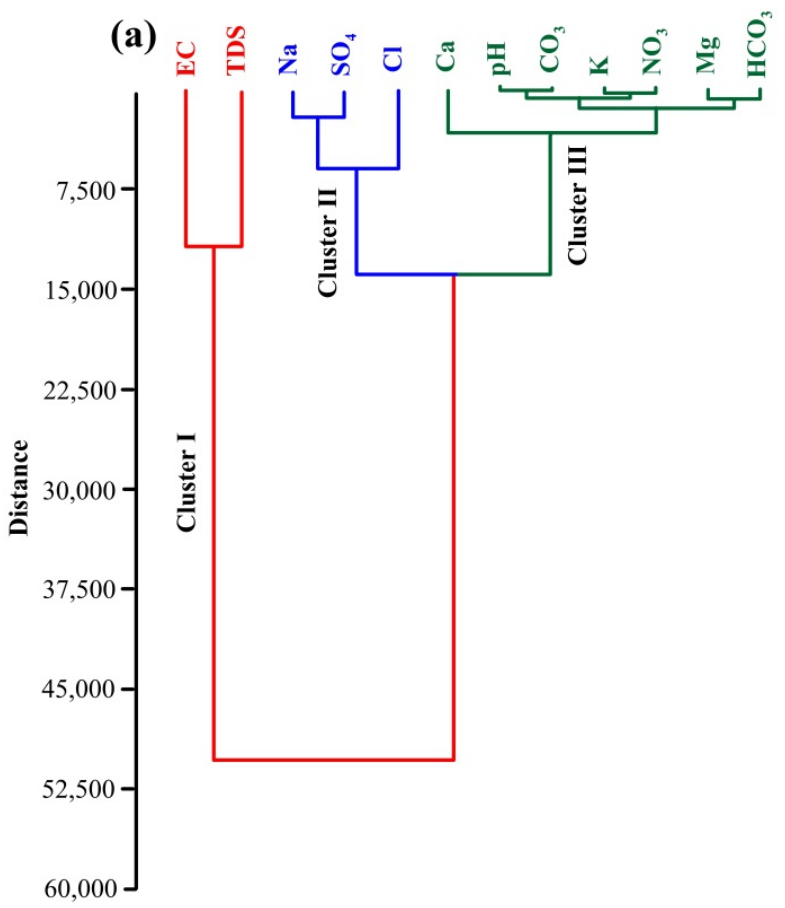

(b)

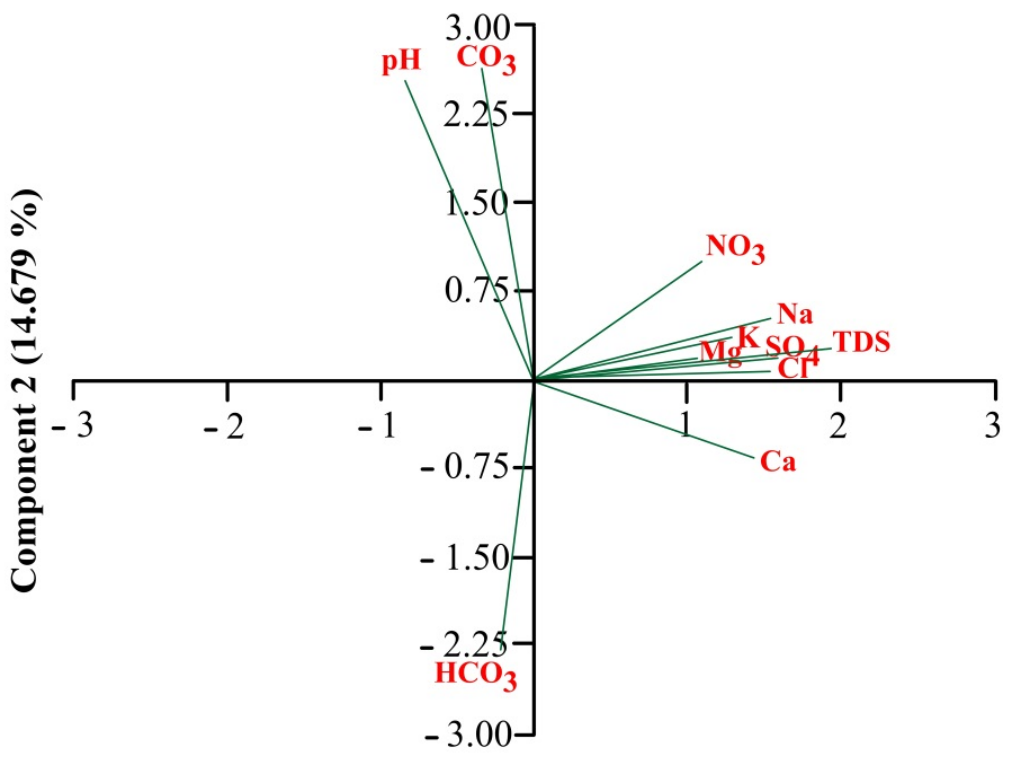

Component 1 (62.775 \%)

Figure 9. Multivariate statistical analysis for physicochemical parameters of groundwater samples in Wadi Fatimah basin: (a) Cluster analysis and (b) Principal component analysis.

According to the PCA results for physicochemical features of major ions in the groundwater samples obtained, large positive loadings of $\mathrm{Na}^{+}, \mathrm{Ca}^{2+}, \mathrm{Mg}^{2+}, \mathrm{K}^{+}, \mathrm{Cl}^{-}, \mathrm{SO}_{4}{ }^{2-}$, and $\mathrm{NO}_{3}{ }^{-}$prevailed over PC1 in explaining $62.775 \%$ of total variance while PC1 explained $14.679 \%$ of the total variance that prevailed by loading of $\mathrm{pH}, \mathrm{HCO}_{3}{ }^{2-}$, and $\mathrm{CO}_{3}{ }^{2-}$ (Figure $9 \mathrm{~b}$ ). The majority of cations and anions were clustered together in positive-loading combinations except for total alkalinity $\left(\mathrm{HCO}_{3}{ }^{2-}\right.$ and $\left.\mathrm{CO}_{3}{ }^{2-}\right)$, which indicated that the variables have a substantial association. According to PCA results, the presence of nine principal components demonstrated the influence of significant ions on groundwater 
quality in the studied region. Therefore, $\mathrm{PC} 1$ presented maximum loading of $\mathrm{Na}^{+}, \mathrm{Ca}^{2+}$, $\mathrm{Cl}^{-}$, and $\mathrm{SO}_{4}{ }^{2-}$, while $\mathrm{PC} 2$ presented maximum loading of $\mathrm{pH}, \mathrm{HCO}_{3}{ }^{2-}$, and $\mathrm{CO}_{3}{ }^{2-}$. These findings could be attributable to evaporation, weathering, saltwater intrusion, and rock-water interaction. Most groundwater samples in the investigated area were highly contaminated with $\mathrm{NO}_{3}{ }^{-}$, as shown by the high positive loading of $\mathrm{NO}_{3}{ }^{-}$in $\mathrm{PC} 1$, which revealed agriculture runoff and the effects of the study region being surrounded by urban sewage flowing through the estuary. Therefore, combining physicochemical characteristics in the PCA for groundwater quality assessment is a helpful and adaptable method with remarkable potential and unique insights.

\subsection{Using Partial Least Square Regression to Predict WQIs for Drinking and Irrigation}

PLSR (Partial Least Square Regression) is a reliable method for modeling complex nonlinear interactions, especially when the relationships between variables are ambiguous. In this investigation, PLSR models were utilized to forecast DWQI based on physicochemical parameters and five irrigation indices (IWQI, TDS, SAR, PS and RSC) based on chemical parameters as illustrated in Table 2. The classical mathematical methods mentioned in this study can be used to produce approximate predictions of the DWQI and five IWQIs of the water samples [52,57-60,81]. In this work, PLSR was investigated as an alternative method for predicting WQIs, considering that it is quick, uncomplicated, and does not require many steps to calculate especially the DWQI and IWQI. In addition, PLSR can be used to select the most effective parameters for calculating DWQI and IWQI. This, in turn, leads to reducing the number of elements that were used in the chemical analysis to calculate WQIs and, finally, decreasing the overall cost. The number and influence of input factors have a big impact on the exact forecast, but all data must be available and cost-effective. Based on many response variables, the PLSR predicts a single model $[45,82,83]$.

Figures 10 and 11 illustrate the relationships of DWQI and five IWQIs between observed and predicted values in a 1:1 scatter plot using PLSR for the Cal. and Val. models. PLSR presented accurate prediction models for WQIs in Cal. and Val. For example, the PLSR models of all IWQs had determination coefficient values of $R^{2}$ ranging from 0.905 to 0.999 in the Cal., and ranging between 0.848 and 0.999 in the Val. datasets (Table 4), and had model accuracy ranging from 0.824 to 0.999 in the Cal., and ranging from 0.817 to 0.989 in the Val. dataset. The RMSE values for DWQI, IWQI, TDS, SAR, PS, and RSC were $7.356,10.516,58.920,0.982,1.370$, and 0.762 in the Cal. dataset, respectively, and were $10.030,13.680,71.985,1.494,1.838$, and 0.87 in the Val. dataset, respectively. The PCs were designated to support the calibration data without over-fitting for the PLSR models of six WQIS, and it ranged from 1 to 9 (Table 4). Similar to this study's prediction of WQIs, Gad et al. [45] discovered that PLSR could be utilized to estimate the DWQI and three surface water pollution indices in the Northern Nile Delta. Elsayed et al. [84] found that the multivariate method of Principal Component Regression (PCR) and machine learning of Support Vector Machine Regression SVMR revealed accurate estimation and produced robust models for forecasting the WQIs in both (Cal.) and (Val.), and they had $\mathrm{R}^{2}$ values varying from 0.48 to 0.99 in the Northern Nile Delta, Egypt. Abowaly et al. [44] recently discovered that the PLSR and multiple linear regression (MLR) models performed the best in predicting the PLI of the soil based on data for the four examined elements, with $\mathrm{R}^{2}$ 0.92-0.94 across the three layers. In general, the PLSR models produced strong and reliable estimates of different indices, with the highest $R^{2}$ and highest slope values near 1.00 as well as the lowest RMSE values in both models. 

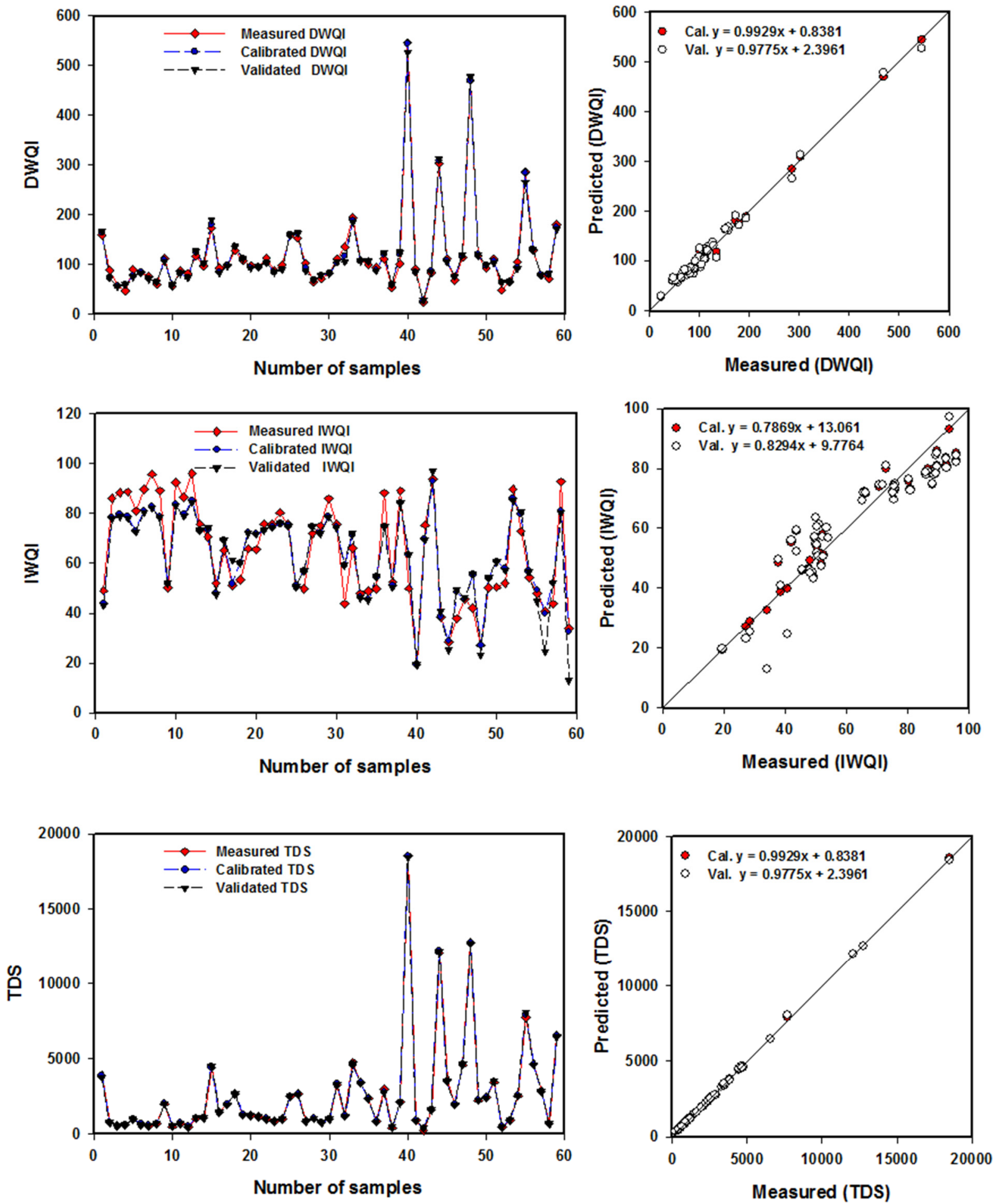

Figure 10. Comparison between measuring datasets, calibrating datasets, and validating datasets for drinking water quality index (DWQI), irrigation water quality index (IWQI), and total dissolved solids (TDS) using PLSR models based on several physicochemical parameters. 

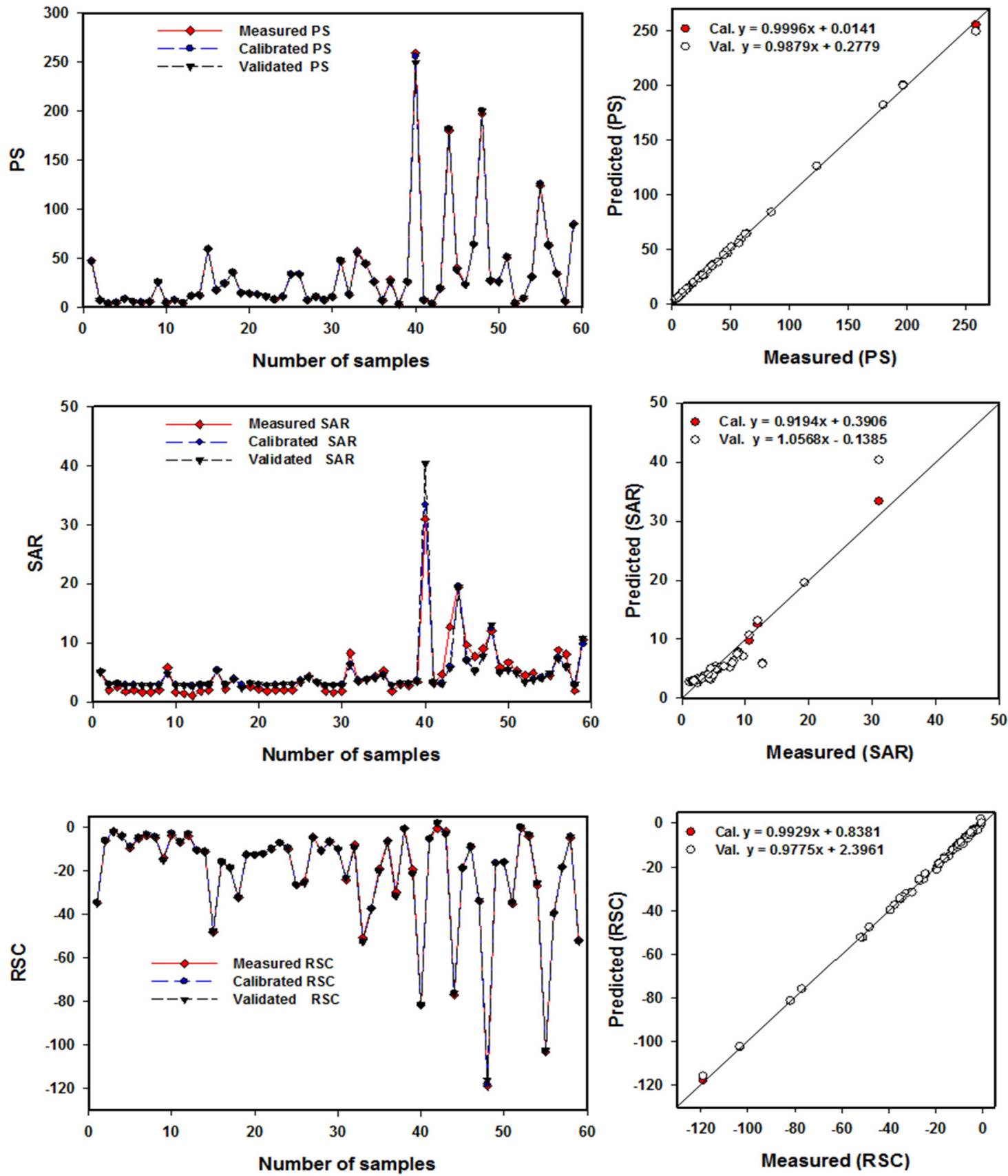

Figure 11. Comparison between measuring datasets, calibrating datasets, and validating datasets for potential salinity (PS), sodium absorption ratio (SAR) and residual sodium carbonate (RSC) using PLSR models based on several physicochemical parameters.

\section{Conclusions}

This study examined the suitability of groundwater in Wadi Fatimah, Saudi Arabia, for drinking and irrigation purposes. Physicochemical characteristics, water quality indices, multivariate modeling as well as GIS techniques were coupled to investigate hydrogeochemical characteristics of the Quaternary groundwater aquifer and corresponding geochemical facies and controlling factors. The analytical results of major ions exhibited the trends of $\mathrm{Na}^{2+}>\mathrm{Ca}^{+2}>\mathrm{Mg}^{+2}>\mathrm{K}^{+}$, and $\mathrm{Cl}^{-}>\mathrm{SO}_{4}{ }^{2-}>\mathrm{HCO}_{3}{ }^{2-}>\mathrm{NO}_{3}{ }^{-}>\mathrm{CO}_{3}{ }^{-}$, respectively. These trends revealed that the hydrochemical facies were $\mathrm{Ca}-\mathrm{HCO}_{3}, \mathrm{Na}-\mathrm{Cl}$, mixed Ca-Mg-Cl-SO ${ }_{4}$, and $\mathrm{Na}-\mathrm{Ca}-\mathrm{HCO}_{3}$. According to the geochemical properties of groundwater, evaporation and saltwater intrusion were the predominant factors controlling the quality of groundwater in the region. DWQI values indicated that the majority 
of inventoried wells, about 95\%, varied between poor to unsuitable class for drinking, requiring proper treatment before use and a water management strategy. IWQI values indicated that about $45.5 \%$ of the samples varied between high to severe restriction class for irrigation use, which can be utilized for the agriculture of high saline sensitivity crops, while $54.5 \%$ of samples varied from moderate to no restriction for irrigation. Agriculture indices like total dissolved solids (TDS), potential salinity (PS), sodium absorption ratio (SAR), and residual sodium carbonate (RSC) showed the mean values of 2572.30, 33.32, 4.84 , and -21.14 , respectively. However, the quality of the groundwater in the study area improves with increased rainfall and thus recharging the Quaternary aquifer.

By calibrating and validating the data sets, the PLSR models were implemented well in estimating the DWQI, IWQI, TDS, SAR, PS, and RSC, with the highest $\mathrm{R}^{2}$, lowest RMSE and MAD values, and highest slope values. For the PLSR models of six WQIs, there were no apparent overfitting or underfitting between measuring, calibrating, and validating datasets. So, a comprehensive picture of water quality and governing mechanisms can be obtained by integrating physicochemical data, WQIs, multivariate modeling, and GIS tools. Therefore, the use of different techniques and indicators that cross-validate was recommended for assessing water quality for general and specific utilization.

Author Contributions: Conceptualization, M.E.O., M.G., S.E., M.M. and A.A.; fieldwork, M.E.O., A.A. and M.M.; methodology, M.G., S.E., M.M. and M.E.O.; software, S.E., M.M. and M.G.; validation, S.E., M.M. and M.E.O.; formal analysis, S.E. and M.E.O.; investigation, M.E.O., A.A. and M.M.; resources, M.E.O., M.M. and A.A.; data curation, M.E.O.; writing original draft preparation, M.E.O., M.G. and S.E.; writing-review and editing, M.E.O., M.G. and S.E.; supervision, M.E.O.; project administration, M.E.O. All authors have read and agreed to the published version of the manuscript.

Funding: This research work was funded by the Deputyship for Research \& Innovation, Ministry of Education in Saudi Arabia, under the project number IFPRC-082-123-2020.

Institutional Review Board Statement: Not applicable.

Informed Consent Statement: Not applicable.

Data Availability Statement: All data are provided as tables and figures.

Acknowledgments: "The authors extend their appreciation to the Deputyship for Research \& Innovation, Ministry of Education in Saudi Arabia, for funding this research work through the project number IFPRC-082-123-2020" and King Abdulaziz University, DSR, Jeddah, Saudi Arabia.

Conflicts of Interest: The authors declare that they have no known competing financial interest or personal relationships that could have appeared to influence the work reported in this paper.

\section{References}

1. Busico, G.; Kazakis, N.; Cuoco, E.; Colombani, N.; Tedesco, D.; Voudouris, K.; Mastrocicco, M. A novel hybrid method of specific vulnerability to anthropogenic pollution using multivariate statistical and regression analyses. Water Res. 2020, 171, 115386. [CrossRef] [PubMed]

2. Aragaw, T.T.; Gnanachandrasamy, G. Evaluation of groundwater quality for drinking and irrigation purposes using GIS-based water quality index in urban area of Abaya-Chemo sub-basin of Great Rift Valley, Ethiopia. Appl. Water Sci. 2021, 11, 148. [CrossRef]

3. Batarseh, M.; Imreizeeq, E.; Tilev, S.; Al Alaween, M.; Suleiman, W.; Al Remeithi, A.M.; Al Tamimi, M.K.; Al Alawneh, M. Assessment of groundwater quality for irrigation in the arid regions using irrigation water quality index (IWQI) and GIS-Zoning maps: Case study from Abu Dhabi Emirate, UAE. Groundw. Sustain. Dev. 2021, 14, 100611. [CrossRef]

4. Danfeng, L. Quantifying water use and groundwater recharge under flood irrigation in an arid oasis of northwestern China. Agric. Water Manag. 2020, 240, 106326.

5. Masoud, M.; Niyazi, B.; Elfeki, A.; Zaidi, S. Mapping of Flash Flood Hazard Prone Areas Based on Integration between Physiographic Features and GIS Techniques (Case Study of Wadi Fatimah, Saudi Arabia). In Proceedings of the 6 International Conference on Water Resources and Arid Environments (ICWRAE 6), Riyadh, Saudi Arabia, 16-18 December 2014; pp. 334-347.

6. Chafouq, D.; El Mandour, A.; Elgettafi, M.; Himi, M.; Chouikri, I.; Casas, A. Hydrochemical and isotopic characterization of groundwater in the Ghis-Nekor plain (northern Morocco). J. Afr. Earth Sci. 2018, 139, 1-13. [CrossRef]

7. Barzegar, R.; AsghariMoghaddam, A.; Adamowski, J.; Nazemi, A.H. Delimitation of groundwater zones under contamination risk using a bagged ensemble of optimized DRASTIC frameworks. Environ. Sci. Pollut. Res. 2019, 26, 8325-8339. [CrossRef] 
8. Ahmed, S.; Kumar, P.; Rozbu, M.; Chowdhury, A.; Nuzhat, S.; Rafa, N.; Mahlia, T.; Ong, H.; Mofijur, M. Heavy metal toxicity, sources, and remediation techniques for contaminated water and soil. Environ. Technol. Innov. 2022, 25, 102114. [CrossRef]

9. Yousefi, H.; Zahedi, S.; Niksokhan, M.H. Modifying the analysis made by water quality index using multi-criteria decision-making methods. J. Afr. Earth Sci. 2018, 138, 309-318. [CrossRef]

10. Adimalla, N.; Dhakate, R.; Kasarla, A.; Taloor, A.K. Appraisal of groundwater quality for drinking and irrigation purposes in Central Telangana, India. Groundw. Sustain. 2020, 10, 100334. [CrossRef]

11. Taloor, A.K.; Pir, R.A.; Adimalla, N.; Ali, S.; Manhas, D.S.; Roy, S.; Singh, A.K. Spring water quality and discharge assessment in the Basantar watershed of Jammu Himalaya using geographic information system (GIS) and water quality Index (WQI). Groundw. Sustain. Dev. 2020, 10, 100364. [CrossRef]

12. Mondal, N.C.; Singh, V.P. Hydrochemical analysis of salinization for a tannery belt in Southern India. J. Hydrol. 2011, 405, 235-247. [CrossRef]

13. Mondal, N.C.; Singh, V.P.; Singh, V.S. Hydrochemical characteristic of coastal aquifer from Tuticorin, Tamilnadu, India. Environ Monit. Assess. 2011, 175, 531-550. [CrossRef] [PubMed]

14. Zhang, W.; Ma, L.; Abuduwaili, J.; Ge, Y.; Issanova, G.; Saparov, G. Hydrochemical characteristics and irrigation suitability of surface water in the Syr Darya River, Kazakhstan. Environ. Monit. Assess. 2019, 191, 572. [CrossRef]

15. Gad, M.; El-Hattab, M. Integration of water pollution indices and DRASTIC model for assessment of groundwater quality in El Fayoum Depression, Western Desert, Egypt. J. Afr. Earth Sci. 2019, 158, 103554. [CrossRef]

16. Gad, M.; El Osta, M. Geochemical controlling mechanisms and quality of the groundwater resources in El Fayoum Depression, Egypt. Arab. J. Geosci. 2020, 13, 861. [CrossRef]

17. Shakeri, A.; Ghoreyshinia, S.; Mehrabi, B. Surface and groundwater quality in Taftan geothermal field, SE Iran. Water Qual. Expo. Health 2014, 7, 205-218. [CrossRef]

18. Gad, M.; Saad, A. Hydrogeochemical evaluation of fractured Limestone aquifer by applying a geochemical model in eastern Nile Valley, Egypt. Environ. Earth Sci. 2017, 76, 641. [CrossRef]

19. Gad, M.; Dahab, K.; Ibrahim, H. Applying of a geochemical model on the Nubian sandstone aquifer in Siwa Oasis, Western Desert, Egypt. Environ. Earth Sci. 2018, 77, 401. [CrossRef]

20. Gad, M.; El-Hendawy, S.; Al-Suhaibani, N.; Tahir, M.U.; Mubushar, M.; Elsayed, S. Combining Hydrogeochemical Characterization and a Hyperspectral Reflectance Tool for Assessing Quality and Suitability of Two Groundwater Resources for Irrigation in Egypt. Water 2020, 12, 2169. [CrossRef]

21. Hussein, H.A.; Ricka, A.; Kuchovsky, T.; El Osta, M.M. Groundwater hydrochemistry and origin in the south-eastern part of Wadi El Natrun, Egypt. Arab. J. Geosci. 2017, 10, 170-184. [CrossRef]

22. Egbueri, J.C. Assessment of the quality of groundwater proximal to dumpsites in Awka and Nnewi metro-polises: A comparative approach. Int. J. Energ. Water Res. 2018, 2, 33-48. [CrossRef]

23. Zhang, X.; Hu, B.X.; Wang, P.; Chen, J.; Yang, L.; Xiao, K. Hydrogeochemical evolution and heavy metal contamination in groundwater of a reclaimed land on Zhoushan Island. Water 2018, 10, 316-338. [CrossRef]

24. Mgbenu, C.N.; Egbueri, J.C. The hydrogeochemical signatures, quality indices and health risk assessment of water resources in Umunya district, southeast Nigeria. Appl. Water Sci. 2019, 9, 22. [CrossRef]

25. Kumar, S.K.; Logeshkumaran, A.; Magesh, N.S.; Prince, S.; Godson, N.; Chandrasekar. Hydro-geochemistry and application of water quality index (DWQI) for groundwater quality assessment, Anna Nagar, part of Chennai City, Tamil Nadu, India. Appl. Water Sci. 2015, 5, 335-343. [CrossRef]

26. Mirzavand, M.; Sadeghi, S.H.; Bagheri, R. Groundwater and soil salinization and geochemical evolution of Femenin-Ghahavand plain, Iran. Environ. Sci. Pollut. R. 2020, 27, 43056-43066. [CrossRef] [PubMed]

27. Kumar, V.; Sharma, A.; Kumar, R.; Bhardwaj, R.; Thukral, A.K.; Rodrigo-Comino, J. Assessment of heavy-metal pollution in three different Indian water bodies by combination of multivariate analysis and water pollution indices. Hum. Ecol. Risk Assess. 2018, 26, 1-16. [CrossRef]

28. Li, P.; Tian, R.; Liu, R. Solute geochemistry and multivariate analysis of water quality in the GuohuaPhosphorite Mine, Guizhou Province, China. Expo. Health 2019, 11, 81-94. [CrossRef]

29. Gad, M.; Abou El-Safa, M.M.; Farouk, M.; Hussein, H.; Alnemari, A.M.; Elsayed, S.; Khalifa, M.M.; Moghanm, F.S.; Eid, E.M.; Saleh, A.H. Integration of Water Quality Indices and Multivariate Modeling for Assessing Surface Water Quality in Qaroun Lake, Egypt. Water 2021, 13, 2258. [CrossRef]

30. Adimalla, N.; Qian, H. Groundwater quality evaluation using water quality index (WQI) for drinking purposes and human health risk (HHR) assessment in an agricultural region of Nanganur, south India. Ecotoxicol. Environ. Saf. 2019, 176, 153-161. [CrossRef]

31. Dimri, D.; Daverey, A.; Kumar, A.; Sharma, A. Monitoring water quality of river ganga using multivariate techniques and WQI (water quality index) in western himalayan region of uttarakhand, India. Environ. Nanotechnol. Monit. Manag. 2021, 15, 100375. [CrossRef]

32. Pak, H.Y.; Chuah, C.J.; Tan, M.L.; Yong, E.L.; Snyder, S.A. A framework for assessing the adequacy of Water Quality IndexQuantifying parameter sensitivity and uncertainties in missing values distribution. Sci. Total Environ. 2021, 751, 141982. [CrossRef] [PubMed] 
33. Uddin, M.G.; Nash, S.; Olbert, A.I. A review of water quality index models and their use for assessing surface water quality. Ecol. Indicat. 2021, 122, 107218. [CrossRef]

34. Yogendra, K.; Puttaiah, E.T. Determination of water quality index and suitability of an urban waterbody in Shimoga Town, Karnataka. In Proceedings of the Proceedings of Taal2007: The 12th World Lake Conference, Jaipur, India, 28 October-2 November 2007; pp. 342-346.

35. Sener, S.; Davraz, A.; Karagüzel, R. Evaluating the anthropogenic and geologic impacts on water quality of the Egirdir Lake, Turkey. Environ. Earth Sci. 2013, 70, 2527-2544. [CrossRef]

36. Arslan, B.; Akün, E. Management, contamination and quality evaluation of groundwater in North Cyprus. Agric.Water Manag. 2019, 222, 1-11. [CrossRef]

37. Shil, S.; Singh, U.K.; Mehta, P. Water quality assessment of a tropical river using water quality index (WQI), multivariate statistical techniques and GIS. Appl. Water Sci. 2019, 9, 168. [CrossRef]

38. Xiao, J.; Wang, L.; Deng, L.; Jin, Z. Characteristics, sources, water quality and health risk assessment of trace elements in river water and well water in the Chinese loess plateau. Sci. Total Environ. 2018, 650, 2004-2012. [CrossRef] [PubMed]

39. National Research Council (US); Committee on Water Quality Criteria. A Report of the Committee on Water Quality Criteria, National Academy of Sciences, National Academy of Engineering; Environmental Protection Agency: Washington, DC, USA, 1972.

40. Wilcox, L.V. Classification and Use of Irrigation Waters; US Department of Agriculture: Washington, DC, USA, 1955.

41. Haque, S.; Kannaujiya, S.; Taloor, A.K.; Keshri, D.; Bhunia, R.K.; Champati Ray, P.K.; Chauhan, P. Identification of groundwater resource zone in the active tectonic region of Himalaya through earth observatory techniques. Groundw. Sustain. Dev. 2020, 10, 100337. [CrossRef]

42. Karuppannan, S.; SerreKawo, N. Groundwater quality assessment using geospatial techniques and WQI in north east of adama town, oromia region, Ethiopia. Hydrospatial Anal. 2020, 3, 22-36. [CrossRef]

43. Yetis, A.D.; Kahraman, N.; Yesilnacar, M.I.; Kara, H. Groundwater quality assessment using GIS based on some pollution indicators over the past 10 Years (2005-2015): A case study from semi-arid harran plain, Turkey. Water Air Soil Pollut. 2021, 232, 11. [CrossRef]

44. Abowaly, M.; Belal, A.; Abd Elkhalek, E.; Elsayed, S.; Abou Samra, R.; Alshammari, A.; Moghanm, F.; Shaltout, K.; Alamri, S.; Eid, E. Assessment of Soil Pollution Levels in North Nile Delta, by Integrating Contamination Indices, GIS, and Multivariate Modeling. Sustainability 2021, 13, 8027. [CrossRef]

45. Gad, M.; Elsayed, S.; Moghanm, F.S.; Almarshadi, M.H.; Alshammari, A.S.; Khedher, K.M.; Eid, E.M.; Hussein, H. Combining Water Quality Indices and Multivariate Modeling to Assess Surface Water Quality in the Northern Nile Delta, Egypt. Water 2020, 12, 2142. [CrossRef]

46. Elsayed, S.; Gad, M.; Farouk, M.; Saleh, A.H.; Hussein, H.; Elmetwalli, A.H.; Elsherbiny, O.; Moghanm, F.S.; Moustapha, M.E.; Taher, M.A.; et al. Using Optimized Two and Three-Band Spectral Indices and Multivariate Models to Assess Some Water Quality Indicators of Qaroun Lake in Egypt. Sustainability 2021, 13, 10408. [CrossRef]

47. Niyazi, b.; Khan, A.; Masoud, M.; Elfeki, A.; Basahi, J. Variability of the geomorphometric characteristics of Makkah Al Mukaramah basins in Saudi Arabia and the impact on the hydrologic response. J. Afr. Earth Sci. 2020, 168, 103842. [CrossRef]

48. APHA. Standard Methods for the Examination of Water and Wastewater, 22nd ed.; American Public Health Association: Washington, DC, USA, 2012.

49. Deutsch, W.J. Groundwater Geochemistry Fundamentals and Application to Contamination; Lewis Publishers: Boca Raton, FL, USA, 1997.

50. Singh, S.; Ghosh, N.C.; Gurjar, S.; Krishan, G.; Kumar, S.; Berwal, P. Index-based assessment of suitability of water quality for irrigation purpose under Indian conditions. Environ. Monit. Assess. 2018, 190, 29. [CrossRef] [PubMed]

51. Cude, C.G. Oregon water quality index a tool for evaluating water quality management effectiveness. J. Am. Water Resour. Assoc. 2001, 37, 125-137. [CrossRef]

52. Brown, R.M.; McClelland, N.I.; Deininger, R.A.; Tozer, R.G.; Water, A. Quality index: Do we dare? Water Sewage Works 1970, 117, 339-343.

53. WHO. Guidelines for Drinking-Water Quality, 4th ed.; World Health Organization: Geneva, Switzerland, 2017.

54. Spandana, M.P.; Suresh, K.R.; Prathima, B. Developing an irrigation water quality index for vrishabavathi command area. Int. J. Eng. Res. Technol. 2013, 2, 821-830.

55. Zaman, M.; Shahid, S.A.; Heng, L. Irrigation water quality. In Guideline for Salinity Assessment, Mitigation and Adaptation Using Nuclear and Related Techniques; Springer International Publishing: Cham, Switzerland, 2018 ; pp. 113-131.

56. Abbasnia, A.; Radfard, M.; Mahvi, A.H.; Nabizadeh, R.; Yousefi, M.; Soleimani, H.; Alimohammadi, M. Groundwater quality assessment for irrigation purposes based on irrigation water quality index and its zoning with GIS in the villages of Chabahar, Sistan and Baluchistan, Iran. Data Br. 2018, 19, 623-631. [CrossRef] [PubMed]

57. Ayers, R.; Westcot, D. Water Quality for Agriculture; FAO Irrigation and Drainage Paper 29 Rev. 1; Food and Agriculture Organization of the United Nations: Rome, Italy, 1994.

58. Doneen, L.D. Notes on Water Quality in Agriculture; Published as a Water Science and Engineering, Paper 4001; Department of Water Science and Engineering, University of California: Oakland, CA, USA, 1964.

59. Richards, L.A. Diagnosis and Improvement of Saline and Alkali Soils [Handbook]. Soil Science; United States Department of Agriculture: Washington, DC, USA, 1954; 78p. 
60. Eaton, F.M. Significance of carbonates in irrigation waters. Soil Sci. 1950, 69, 123-134. [CrossRef]

61. Gupta, S.K.; Gupta, I.C. Management of Saline E Waste Water in Agriculture; Scientific Publishers: Jodhpur, India, 2015.

62. Piper, A.M. A graphic procedure in the geochemical interpretation of water-analyses. EOS Trans. Am. Geophys. Union 1944, 25, 914-928. [CrossRef]

63. Chadha, D.K. A proposed new diagram for geochemical classification of natural waters and interpretation of chemical data. Hydrogeol. J. 1999, 7, 431-439. [CrossRef]

64. Gibbs, R.J. Mechanisms controlling world water chemistry. Science 1970, 170, 1088-1090. [CrossRef]

65. Giménez-Forcada, E.; San Román, F.J.S. An excel macro to plot the HFE-Diagram to identify seawater intrusion phases. Ground Water 2015, 53, 819-824. [CrossRef] [PubMed]

66. Sharaf, M.A.M. Major elements hydrochemistry and groundwater quality of Wadi Fatimah, West Central Arabian Shield, Saudi Arabia. Arab. J. Geosci. 2013, 6, 2633-2653. [CrossRef]

67. Yechieli, Y.; Wood, W.W. Hydrogeologic processes in saline systems: Playas, Sabkhas, and Saline Lakes. Earth Sci. Rev. 2002, 58, 343-365. [CrossRef]

68. Monjerezi, M. Groundwater Salinity in Lower Shire River Valley (Malawi) Hydro-Geochemical and Isotope Constraints on Sources and Evolution; University of Oslo: Oslo, Norway, 2012; 188p.

69. Berner, E.; Berner, R. Global Environment: Water, Air and Geochemical Cycles, 2nd ed.; Princeton University Press: Princeton, NJ, USA, 2012

70. Adimalla, N.; Taloor, A.K. Hydrogeochemical investigation of groundwater quality in the hard rock terrain of South India using Geographic Information System (GIS) and groundwater quality index (GWQI) techniques. Groundw. Sustain. Dev. 2020, 10, 100288. [CrossRef]

71. Yasmin, G.; Islam, D.; Islam, M.T.; Shariot-Ullah, M.; Adham, A.K.M. Evaluation of groundwater quality for irrigation and drinking purposes in Barishal district of Bangladesh. Fundam. Appl. Agric. 2019, 4, 632-641. [CrossRef]

72. Davis, S.; Dewiest, R. Hydrogeology; Wiley: New York, NY, USA, 1966.

73. Puntamkar, S.; Kant, K.; Mathur, S. The effect of saline water irrigation on soil properties. Trans. Indian Soc. Desert Technol. Univ. Cent. Desert Stud. 1988, 13, 69-72.

74. Srinivasamoorthy, K.; Gopinath, M.; Chidambaram, S.; Vasanthavigar, M.; Sarma, V.S. Hydrochemical characterization and quality appraisal of groundwater from Pungar sub basin, Tamilnadu, India. J. King Saud Uni. Sci. 2014, 26, 37-52. [CrossRef]

75. Subramani, T.; Elango, L.; Damodarasamy, S.R. Groundwater quality and its suitability for drinking and agricultural use in Chithar River Basin, Tamil Nadu, India. Environ. Geol. 2005, 47, 1099-1110. [CrossRef]

76. Suarez, D.L.; Wood, J.D.; Lesch, S.M. Effect of SAR on water infiltration under a sequential rain-irrigation management system. Agric. Water Manag. 2006, 86, 150-164. [CrossRef]

77. Todd, D.K. Groundwater Hydrology, 1st ed.; John Wiley and Sons, Inc.: Hoboken, NJ, USA, 1960; 336p.

78. Sudhakar, A.; Narsimha, A. Suitability and assessment of groundwater for irrigation purpose: A case study of Kushaiguda area, Ranga Reddy district, Andhra Pradesh, India. Adv. Appl. Sci. Res. 2013, 4, 75-81.

79. Sundaray, S.K.; Nayak, B.B.; Bhatta, D. Environmental studies on river water quality with reference to suitability for agricultural purposes: Mahanadi river estuarine system, India-A case study. Environ. Monit. Assess. 2009, 155, 227-243. [CrossRef]

80. Ravikumar, P.; Somashekar, R.K.; Angami, M. Hydrochemistry and evaluation of groundwater suitability for irrigation and drinking purposes in the Markandeya River basin, Belgaum District, Karnataka State, India. Environ. Monit. Assess. 2011, 173, 459-487. [CrossRef] [PubMed]

81. Meireles, A.C.M.; Andrade, E.M.; Chaves, L.C.; Frischkorn, G.H.; Crisóstomo, L.A. A new proposal of the classification of irrigation water. Rev. Ciênc. Agron. 2010, 41, 349-357. [CrossRef]

82. Mustapha, A.; Aris, Z.A. Multivariate statistical analysis and environmental modelling of heavy metals pollution by industries. Pol. J. Environ. Stud. 2012, 21, 1359-1367.

83. Chen, J.; Lu, J. Effects of land use, topography and socio-economic factors on river water quality in a mountainous watershed with intensive agricultural production in East China. PLoS ONE 2014, 9, e102714. [CrossRef] [PubMed]

84. Elsayed, S.; El-Gozayer, K.; Allam, A.; Schmidhalter, U. Passive reflectance sensing using regression and multivariate analysis to estimate biochemical parameters of different fruits kinds. Sci. Hortic. 2019, 243, 21-33. [CrossRef] 